Florida International University FIU Digital Commons

\title{
Blessed are the Peacemakers: Transnational Alliance, Protective Accompaniment and the Presbyterian Church of Colombia
}

Michael C. Brasher

FIU, mcbrash00@gmail.com

DOI: $10.25148 /$ etd.FI13042326

Follow this and additional works at: https://digitalcommons.fiu.edu/etd

Part of the Ethics in Religion Commons, History of Christianity Commons, $\underline{\text { History of Religion }}$ Commons, Human Geography Commons, Latin American History Commons, Latin American $\underline{\text { Languages and Societies Commons, Missions and World Christianity Commons, Race, Ethnicity }}$ and Post-Colonial Studies Commons, and the Religious Thought, Theology and Philosophy of Religion Commons

\section{Recommended Citation}

Brasher, Michael C., "Blessed are the Peacemakers: Transnational Alliance, Protective Accompaniment and the Presbyterian Church of Colombia" (2013). FIU Electronic Theses and Dissertations. 885.

https://digitalcommons.fiu.edu/etd/885 


\title{
FLORIDA INTERNATIONAL UNIVERSITY \\ Miami, Florida
}

\section{BLESSED ARE THE PEACEMAKERS: TRANSNATIONAL ALLIANCE, PROTECTIVE ACCOMPANIMENT AND THE PRESBYTERIAN CHURCH OF COLOMBIA}

\author{
A thesis submitted in partial fulfillment of \\ the requirements for the degree of \\ MASTER OF ARTS \\ in \\ LATIN AMERICAN AND CARIBBEAN STUDIES
}

by

Michael C. Brasher 
To: Dean Kenneth Furton

College of Arts and Sciences

This thesis, written by Michael C. Brasher, and entitled Blessed are the Peacemakers: Transnational Alliance, Protective Accompaniment and the Presbyterian Church of Colombia, having been approved in respect to style and intellectual content, is referred to you for judgment.

We have read this thesis and recommend that it be approved.

\begin{tabular}{ll}
\hline Andrea Fanta \\
\hline Ulrich Oslender
\end{tabular}

Ana Maria Bidegain, Major Professor

Date of Defense: March 28, 2013

The thesis of Michael C. Brasher is approved.

$\begin{array}{r}\text { Dean Kenneth Furton } \\ \text { College of Arts and Sciences } \\ \hline \begin{array}{r}\text { Dean Lakshmi N. Reddi } \\ \text { University Graduate School }\end{array}\end{array}$

Florida International University, 2013 
(C) Copyright 2013 by Michael C. Brasher

All rights reserved. 


\begin{abstract}
OF THE THESIS
BLESSED ARE THE PEACEMAKERS: TRANSNATIONAL ALLIANCE, PROTECTIVE ACCOMPANIMENT AND THE PRESBYTERIAN CHURCH OF

COLOMBIA
\end{abstract}

by

Michael C. Brasher

Florida International University, 2013

Miami, Florida

Professor Ana Maria Bidegain, Major Professor

Studies of transnational alliance emphasize a strategy whereby groups in different nations strive to strengthen one another's leverage and credibility in order to resolve common conflicts and elaborate new possibilities. These strategies have been categorized at various times as globalization from below, the global justice movement, and altergeopolitics. Although the merits of transnational alliance in general have been analyzed among civil society sectors, few analyses have considered that religious communities increasingly use these strategies to strive for justice and equality. The following case examines the emergence of these trends within the history of the Presbyterian Church of Colombia in order to assess the potential of religious networks to uniquely enable transnational alliance. 


\section{TABLE OF CONTENTS}

CHAPTER

PAGE

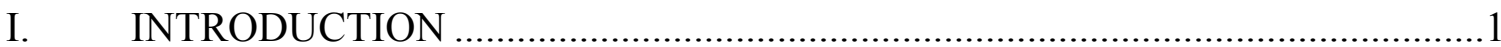

II. CHRISTIANITY AND CAPITALIST EXPANSION …..................................

III. GIANTS UNDER GOD: MISSIONARIES AND CAPITAL …........................15

SIL AND THE LINGUISTICS OF EMPIRE ........................................16

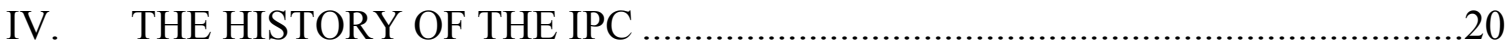

CHALLENGES OF THE EARLY PERIOD: 1850-1960 …....................22

REFORMAR Y REFORMARSE: 1960-PRESENT ...............................40

V. THE IPC NOW: GEOPOLITICS, ALLIANCE AND RESISTANCE ...............66 GEOPOLITICS AND TRANSNATIONAL STRATEGIES ....................69 PROTECTIVE ACCOMPANIMENT …............................................... 71 THE EMERGENCE OF ACCOMPANIMENT IN THE IPC …..............73 IPC ACCOMPANIMENT: THE ETHIC OF PARTNERSHIP ................77

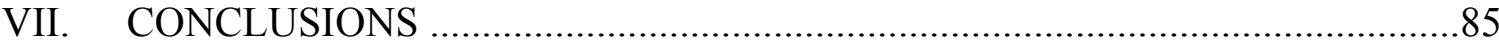

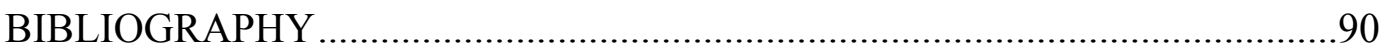

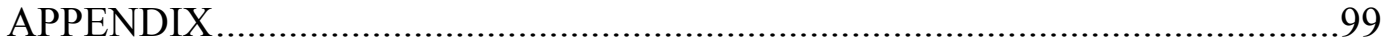




\section{Introduction}

In June of 1983, the groups Peace Brigades International and Witness for Peace sent a delegation of U.S. volunteers into communities threatened by the U.S.-backed Contras along the Honduran-Nicaraguan border. Widespread reports of massacres had been coming out of this region and the goal of the delegation was to investigate these reports and make public their findings. When they came to the village of El Porvenir, it was clear that the city had been under siege, and as the delegation exited the bus they could still see the Contra forces receding into the jungle across the border. Villagers ran to the newly arrived group, telling them that the only reason they were not still being attacked was that the foreigners were there (Eugene and Mahoney 1997). This event represents a seminal moment in the development of the strategy of Third Party Nonviolent Intervention (TPNI), more conventionally known as protective accompaniment. Accompaniment involves placing privileged bodies, ones that are either less threatened or less likely to be threatened, alongside bodies that are at risk or under threat. A complicated strategy, the natural question that emerges is: does this type of practice reify systems that privilege certain bodies over others, or does it take advantage of those systems in order to struggle for a world in which all bodies enjoy the privilege of security?

Accompaniment has been a particularly effective example of transnational alliance (Duncan, Zissaman, and Savaiano 2009). As seen in the accompaniment model, transnational alliance at its most basic level refers to the ways that groups in different nations strive to strengthen one another's leverage and credibility in order to resolve common conflicts and elaborate new possibilities. Although the merits of protective 
accompaniment in particular and transnational alliance in general have been analyzed among civil society sectors, few analyses have considered that religious communities increasingly use these strategies to strive for justice and equality.

I first found out about protective accompaniment as the result of a Spanish grammar course that I took during my undergraduate at a small, Pentecostal University in rural Tennessee. The professor of that course was a Colombian, and always talking about the work of the Presbyterian Church of Colombia (Iglesia Presbiteriana de ColombiaIPC). I had never heard much about the Presbyterians - certainly nothing that merited sustained enthusiasm — and in the summer of 2010 he invited me to travel to Colombia with him to see firsthand what his home Church was doing. The community had developed a protective accompaniment program in order to protect themselves from the continuous threats they had received since beginning advocacy work for the city's displaced population in the middle of the 1990's.

This was only one of a series of transnational alliances that the church has been forging to aid in their struggle for peace and justice amid the national conflict. They had also formed a series of "hermandades," informal contracts between Presbyterian churches in the U.S. and Colombia. Through the hermandades, a specific church community in Colombia would link up with a specific U.S. church community, agreeing to work with one another for a period of 4 years. During this period, groups send delegations to visit the other church, share worship services via Skype, and commit to prayerfully accompany one another in their struggles. My Spanish professor's presence in rural Tennessee was actually a result of such an alliance. A member of an Ohio delegation had invited him and his wife to come to Miami, Ohio, where they completed a Masters 
program before going on to do their $\mathrm{PhD}$ at the University of Florida. Soon they had jobs teaching Spanish at a small Pentecostal school, and I was spending my summer in Barranquilla with the Presbyterians.

In setting out to conduct a research project on the strategies of transnational alliance employed by the Presbyterian Church of Colombia (IPC), three principal questions predominated. First, how has the IPC come to form these strategies? This was a question of historical development, and recovering that history became the dominant goal of this research. Second, in what ways has their being a religious group distinctly impacted their deployment of these strategies? Unions, NGOs and other civil society groups have been deploying such strategies for quite some time. How, then, does religion as the uniting factor between these different communities affect the ways that they work together? The third and final question concerns the fact that the network of relations between the Colombian and U.S. Presbyterian communities has been going on for over 150 years. What is the signification of the duration of their relationship in strategies of transnational alliance?

In order to answer these questions I travelled to Colombia during the summer of 2012. I spent most of my time in and around Bogotá, Barranquilla, and Medellín. Because the principal focus of this research was to recover the history of the IPC network, I spent time with the only person that's written extensively on the Church, Dr. Javier Rodríguez. Dr. Rodríguez is the Moderator of the IPC, and the director of one of their most important schools, the Colegio Americano de Bogotá. I conducted formal interviews with Dr. Rodríguez on July $21^{\text {st }}$ in Itagüí, Antioquia, and August $8^{\text {th }}$ in Bogotá. He also granted me access to the archival material not only from his personal collection, 
which included unpublished manuscripts and the correspondences of important church leaders, but also from the IPC archive located in the Colegio Americano Library.

Next I conducted a series of open-ended interviews with 20 leaders of the IPC community. This group has been leading the church since a decisive shift took place following a division in the community in the early 1990's (to be discussed below). Composed of 7 females and 13 males, these leaders come from a range of positions including pastors, professors, school counselors, administrators and members of the board of the IPC. Working together, they have sought to develop and extend their current network of transnational alliances. In addition, I organized a series of focus groups, which allowed me to recover the experiences of more than 50 community members affected by both the national conflict and the IPC advocacy programs in the department of Atlántico. The source and method of recruitment was referral through the Director of the office of Diaconia, which oversees the IPC's outreach and advocacy programs, German Zarate. Lastly, I interviewed two long-term accompaniers, Richard Williams and Mamie Broadhurst, who have spent three years in the country both doing accompaniment work and helping to facilitate the experience of short-term accompaniers. ${ }^{1} \mathrm{~A}$ formal interview was conducted on July 25 at the IPC headquarters in Barranquilla, although I had opportunities for informal conversations with the pair throughout my time in Colombia.

A number of theoretical perspectives and literatures impacted the way that I approached this research. The first body of literature related to transnationalism. The

\footnotetext{
${ }^{1}$ The model of accompaniment in the IPC is to have 2 long-term accompaniers that make 3 -year commitments, while every 30 days a fresh pair of accompaniers comes and goes.
} 
work of Nina Glick Shiller (2004) on reforming basic conceptions of social formations was pivotal to my understanding of the IPC network. According to Glick Shiller, amid the rapid changes in migratory flows, communication technologies and linked markets that have corresponded to recent phases in neoliberal globalization, we need new conceptual frameworks in order to consider what a society is. Most of us today are sustained through relationships that stretch across time and space, and looking at the map of a nation or state cannot adequately capture these social formations. Rather if we were to map out the kinds of connections that comprise our individual or communal social formations they would look quite different.

The lives of increasing numbers of individuals can no longer be understood by looking only at what goes on within national boundaries. Our analytic lens must necessarily broaden and deepen because migrants are often embedded in multilayered, multi-sited transnational social fields.... As a result, basic assumptions about social institutions such as the family, citizenship, and nation-states need to be revisited. (Levitt and Shiller 2004, p. 1005)

Glick Shiller is developing this work through the idea of "simultaneity," which expresses how we engage in ways of being and ways of belonging through various places at once.

Such a framework enabled me to begin to see and understand various ways that the transnational alliance of the Colombian Presbyterian network might function.

In addition to Glick Shiller's work, the literature on "globalization from below" has been useful. Similarly responding to recent developments in global connections, this literature seeks to show how distinct communities are linking up to challenge the oppressive qualities of the global socio-economic and political system (Brecher et al., 2000). According to Jackie Smith, the distinction between a world economic system ("globalization from above") and a global society ("globalization from below") is that the 
latter works toward "a vision of globalization based on cooperation and inclusion rather than economic competition" (2008, p. 5). What Daly (2002) has similarly described as "internationalization", globalization from below involves the strategic linking of formal and informal networks "to coalesce into a transnational civil society" (Bandy and Smith 2005, p. 231;). Additionally, Guidry et al. explain the concept of a "transnational public sphere" as "a space in which both residents of distinct places (states or localities) and members of transnational entities (organizations or firms) elaborate discourses and practices whose consumption moves beyond national boundaries" (2000, p. 6-7). More recently, these movements are described as the Global Justice Movement (Hosseini 2009). While much has been said about the subversive potential of these movements, few analyses have considered the capacity of transnational religious networks to facilitate important challenges to top-down models of political and economic policy often identified with neoliberal globalization. Here, my analysis of the case of the IPC intervenes by showing how these religious communities' struggles to articulate justice within their own network of relations have led to a creative and effective period of transnational alliance.

The second lens that proved crucial to this research is that of Post- and Decolonial literature (Escobar and Mignolo 2010; Escobar 2008; Mignolo 2005; Maduro 2004; Slater 2004; Gregory 2004; Mbembe 2001). This literature allowed me to appreciate not only what was at stake in the movement of North American missionaries travelling to evangelize Colombians, but also what it means for the IPC to confront, redress and reform their relationships with North American counterparts. This body of work was also pivotal in helping me to thoughtfully consider and negotiate my own role as a U.S. 
academic travelling in Colombia to gather data for an academic project. Without it, I would have been unable to understand the data I gathered and form genuine relationships with community members while there.

The last analytical framework that contributed to this project was that of Critical Geography (Toal 1996; Dowler and Sharp 2001; Oslender 2007 \& 2008; Elden 2009; Koopman 2011). Specifically the subfield of Critical Geopolitics, first introduced to me by Dr. Ulrich Oslender, was crucial. If typical geopolitics is the work of elites to map out territories and manipulate publics in order to gain control over important resources, critical geopolitics considers the interests of those publics in asking, how, why and for whom are such organizations of space made? It problematizes taken-for-granted assumptions about space by questioning whose interests are represented by the dominant organization of territories. Sara Koopman (2011) has contributed to this field with the concept of alter-geopolitics. While critical geopolitics seeks to push back against the dominant modes of statecraft, alter-geopolitics uses feminist geography to analyze geopolitics at the scale of the body in order to analyze how bodies are coming together to produce space in new ways, to produce what they do want. Koopman also analyzes civil society accompaniment programs in Colombia, and her work aligns with the aforementioned literature on transnational alliance and solidarity.

The largest section of the data collected relays the history of the IPC, ranging from the 1850 's to the present, with another section that treats the present period of the IPC. Before considering the case, I offer two general reflections. The first concerns the historical relationship between the Christian religion and the unfolding of the modern state system through capitalist expansion. As the historical processes of the state and 
capital have been determinative for the modern global system that dominates now, the ways that Christianity has historically both coaxed and confronted that system necessarily foreground the IPC history.

Next, I situate the complex ways that foreign, Christian missionaries have related to Latin America by reviewing the case of the Summer Institute of Linguistics (SIL). The SIL is one of the most popular examples of how missionaries have often functioned in the region at the intersection of faith and imperialism. Combining these reflections with a review of the case of the Presbyterian Church of Colombia, this thesis argues that while Christianity has historically functioned, quite obviously, at the service of the modern geopolitical, socio-economic order, it is also evident that portions of the Christian religion have consistently and passionately worked to confront, challenge and change that system. This assertion coalesces with the work of sociologist Otto Maduro (2004). He points out that a postcolonial emphasis on religion as action, as process, as production - rather than belief, belonging, or instituted institution - points toward increasing attention to how concrete groups and individuals $d o$ religion; to what they actually $d o$ as religion; to what they do of and for themselves, for and to each other, with and through religion; including what they sometimes do despite and over against their own religion(s); as well as to what they do to religion itself and to its meanings in these processes. This seems to be at least a fertile complement, if not a counterweight, to studies too tangled in a view of 'religions' as tangible, given, pre-existing, established institutions. (p. 12-13)

The spaces where distinctions between faith and oppression have taken place are at best murky, on scales both global and intimate. Over time, Christian movements and individuals have had maturing relationships to dominant systems of practice and thought. A closer look at the IPC case shows that, out of these tensions and shifts, a network may mature. The complex periods and commitments that at different times predominated the 
movements of the Presbyterian network in Colombia are not forgotten, and individual appreciation for this complex history seems to be bringing a thoughtful, "listening" ethic to the ways that relationships are forged now, strengthening particular political practices. The suggestion behind the research is that some elements of transnational Christian networks, for all their sullied histories, may have significant potentials to employ contemporary political strategies that contribute to global movements seeking to reorganize life around ideas of justice and peace.

\section{RELIGION AND CAPITALIST EXPANSION}

To talk about how Christian religious networks may challenge contemporary processes of globalization requires a more fundamental consideration of the historical relationship between religion and processes of capitalist expansion altogether. Despite often being considered the mascot of the Capitalist system, the story between Christianity and capitalism has been much longer and more complex than is often considered. Both essential components of a project termed modernity, their historical unfolding demonstrates an interrelation. Even beyond their chronological correspondence to the project of modernity, capitalism and Christianity flow out of the same founding myth: the logic of universality. Yet in spite of their commonalities, the relationship has also been one that has vacillated between complementarity and conflict.

Both the Christian and capitalist project coalesce around global aims. The process of expansion under colonialism entwined the movement of capital with cosmologies, as Europeans brought with them their own form of religiosity (Althaus-Reid 2000, p. 1118). The premise of "civilizing" the savages, spreading the gospel, and converting the 
heathen as fundamental to the colonial endeavor is well documented. ${ }^{2}$ Nevertheless, the subsequent rise of the nation-state proved to be one of the most problematic negotiations between Christianity and capital expansion. The role of the nation-state with regards to the Christian religion is even more complex due to the opposing positions held by the Catholics and the Protestants. The Catholic Church was hostile to alliances based on the nation-state, and only began to recognize some autonomy among the national Churches in the 19th century. Protestants, for their parts, tended to side with the liberal project and favored the increase in national powers which would preserve some domains of public life from the reach of the Catholic Church.

According to Dr. Ana Maria Bidegain (2008), Christianity as uniquely a transnational institution is one consequence of the Catholic hierarchy's reaction to the rise in the power of the nation-state during the 19th century, which had resulted, for them, in losses of influence, Italian territory and other resources. It first responded by symbolically concentrating all the strength of the Church more fully into the papacy, further centralizing the power of the institution to endure through space and resist the reach of the growing nation-states. Yet in order to become an effective supranational entity, the Church needed to develop a vital web of relations and communication between all of the territories it inhabited. This network enabled them to have a clear line of authority and hierarchy while simultaneously being connected throughout the world that was being reconfigured by European force. In addition to the formal network of hierarchy established through bishops, other Christian orders, such as the Jesuits, the Franciscans,

\footnotetext{
${ }^{2}$ Later discourses of Manifest Destiny and the White Man's burden perpetuated this interrelation.
} 
Nuns and lay organizations, sprang up all throughout both Europe and the newly colonized worlds, consolidating further the networks of the Christian Church (Langan 1998).

Because capitalist expansion through colonization meant the spreading of the Christian network, ${ }^{3}$ Catholics supported the project, and so Christianity seemed to align with the global movement of capitalism. However the conflict arises because, while the global intentions are the same, the manner in which capitalist expansion takes place, the social and economic dynamics of the process, contradicts the socio-religious ethics of certain movements within the religion. For those Christian individuals or communities that place the dignity and respect of human beings at the center of their faith, the reality of capital's exploitation of particular groups of people contradicts the ethical basis of the Christian message. When those Christians have seen the way that the capitalist system of expansion secures its profits through the disregard of the life and dignity of particular groups, they've sought to confront and challenge that system. Despite the role of Christian missionaries and ideology in the massacre of indigenous people under the colonial project, dominican Friar Bartolomé de las Casas spoke out against those slaughters and mistreatments in the West Indies ${ }^{4}$ (Todorov 1984). Later, the rise of Latin American Liberation Theology would call attention to the contradictions between the

\footnotetext{
${ }^{3}$ While this process enjoyed Catholic support from the $16^{\text {th }}$ to $18^{\text {th }}$ century, following the Iberian empire, particularly in the Americas, Protestants followed with their support of the colonial project in the $19^{\text {th }}$ and $20^{\text {th }}$ through European and U.S. imperialism; this becomes evident in the case of the IPC, discussed below.

${ }^{4}$ Of course, it is well known that de las Casas is a more complex figure, having also influenced the development of the transatlantic African slave trade. But even what we know of his life shows that the intersection of faith and oppressive systems is dynamic and processual.
} 
view that Christ's life was liberatory and the processes of capital exploitation throughout the world (Müller et al. 2000). This trend hasn't been restricted to Christianity alone. Hasenclever and Rittberger (2000) recall that "social movements which do not only strive for radical political reforms but also commit their followers to strict nonviolence arose time and again from the midst of the great world religions" (p. 668).

Nevertheless, the complex relationship between Christianity and capital expansion has persisted. Despite advocacy for human rights and justice on the part of Christian groups-including the important influence of progressive theology at the Second Vatican Council— the Church has continued to play an ambivalent role with regards to the capitalist system. Overall, after the establishment of the hegemony of the nation-state, the Church as an institution has been aligned with the state and ruling class interests, siding with and legitimizing processes of capital exploitation. The disagreement within Christianity about how the Gospel message related to the capitalist system was highlighted and exacerbated by the dynamics of the Cold War, which at times delineated the world into freedom-loving advocates for capitalism and repressive, communist subversives. This imposition led to further schisms throughout the Christian world as groups that supposedly shared the same faith were split into geopolitical and ideological factions. Many Christian Churches in Latin America, of various denominations and sects, experienced splits and schisms throughout the decades of the Cold War as members disagreed about how the faithful should respond to the pressing political conflicts of the time. During this period, many Christian communities in the U.S. supported President Ronald Reagan and argued for the merits of the Washington Consensus ${ }^{5}$ in Latin

${ }^{5}$ The Washington Consensus refers to a model of relations between the U.S. and other 
America (Moreton 2007; Brouwer et al. 1996), while other Christian group struggled for justice in spite of the capitalist and imperialist systems manifested by the state. Such struggles recall the cases of both Father Camilo Torres and the group, largely comprised of Presbyterian members and led by Orlando Fals Borda, the Rosca de Investigación, to be discussed below (Smith 1996a; 1996b).

Since the end of the Cold War, the global Christian community has continued to struggle to articulate unified responses about how the notion of human beings as the image of God may relate to the oppressive lived reality for so many under the dominant system of states and markets. However, what seems to be a new chapter in the Church's response is the capacity to generate more potent forms of advocacy and response over and against that system (Bidegain 2008). The impact of the Second Vatican Council still resonates, and is often underestimated. Although later Church leaders would attempt to undermine much of the work accomplished in Medellín after Vatican II, its emphasis on the poor, the working class, and laity in general, opened up fresh space to consider the role of the people in the work of the Gospel (Rodríguez 1992). A radically more democratic environment emerged from Medellín, and the emphasis on the validity and importance of other faiths and inter-faith dialog has allowed groups that before would never have collaborated (not only Protestants and Catholics but also indigenous and secular groups) to come together in solidarity as they struggle to fulfill a common vision

countries that insists that, as capitalism is consistent with freedom, other countries should imitate the Liberal policies and design of the U.S. economic system in order to resolve their particular local problems. More specifically, the term describes the dispositions and practices of the U.S. towards Latin America during the Cold War, exemplified by Reagan's assistance to the Contra forces in Nicaragua, referenced above. 
for a world more oriented toward justice and equality. ${ }^{6}$ In addition, technological innovation and new methods of communication have enabled links and alliances across space whereas, before these technologies had made connection possible, relevant groups may have remained isolated within the general panorama of Christian activity. Bidegain (2010) affirms that "one important characteristic of this new form of Christianity is the capacity to create new and adaptive forms of religion" (p. 174). These developments suggest that religious groups have an important role to play in linking communities and enabling common struggles for justice.

Amid these shifts, the vision of some groups within the Christian network for a gospel of justice and equality continues to animate a spirit of resistance. Just as Bartolomé de las Casas became a radical advocate for indigenous rights when faced with the reality of colonization, modern missionaries and religious groups from the global north continue to spend time in those parts of the world where the devastating consequences of capital expansion and global imperialism are most materially evident. Many of those individuals, confronted by the ideals of their faith, make commitments and connections to struggle in solidarity with communities suffering under the dominant system. Despite the ambiguous historical role that the Christian faith has played in the project of capital expansion, today Christian networks and values enable individuals and communities from across the globe to forge transnational connections in order to confront and challenge the consequences of global capitalism (Barker 2007; Smith 1996a, 1996b).

\footnotetext{
${ }^{6}$ Declaración sobre la Libertad Religiosa (December 7, 1965); Declaración sobre las Relaciones de la Iglesia con las Religiones no Cristianas (October 28, 1965). In Concilio Vaticano II: Constituciones, Decretos, Declaraciones. Biblioteca de Autores Cristianas: Madrid, 1965.
} 


\section{GIANTS UNDER GOD: MISSIONARIES AND CAPITAL}

The effect of capitalist expansion in Latin America has been further complicated by the activity and use of missionaries. There is a story that Desmond Tutu likes to tell about missionaries in Africa. "When the missionaries first came to Africa, they had the Bible and we had the land. They said, 'Let us pray.' We closed our eyes. When we opened them we had the Bible and they had the land" (Gish 2004, p. 101). The nature of such exchanges inevitably touches the bond shared by religion and empire.

Contemporary discussions regarding the relationship between Church and State draw on their robust interrelated history. Ancient Roman attempts to unify the empire repeatedly signaled a call to imperial cohesion through religious sacrifice, primarily civic in nature. The profusion of martyr theology in early Christian communities gives testimony to the inherently political nature of one's response to the imperial call for religious assimilation.

The relationship between a missionary's understandings of what she is doing and the way that her beliefs and practices are situated within the broader constellation of geopolitical shows nuance. While an individual may trust her simple desire to spread the "good news" of her faith, larger epistemes and discourses related to race and progress may underlay her desire. For this reason, it's important to consider the dynamics whereby sincere, religious individuals, in proselytizing, unknowingly participate in the export of their own national geopolitical interests. Conversely, it's important to recognize that religious movements are often quite intentionally co-opted for hegemonic political purposes. Both the missionary and evangelism have played a major role in the growth of the dominant system. What follows offers a cursory reflection on the relationship 
between the spread of certain North American religious traditions in Latin America and U.S. economic and political policies in the region by way of the history of the Summer Institute of Linguistics (SIL). Reviewing this case serves not only to identify what's at stake in the story of the Colombian Presbytery but also to recognize the complex and problematic history of Christian religious networks.

\section{SIL AND THE LINGUISTICS OF THE EMPIRE}

We are only in the very dawn of commerce, and we owe that dawn, with all its promise to the channels opened up by Christian missionaries .... The effect of the missionary enterprise of the English speaking peoples will be to bring them the peaceful conquest of the world. ${ }^{7}$

The story of the SIL, run by a group better known in the United States as the Wycliffe Bible Translators (WBT), has been disputed at length by anthropologists and missionaries for some time (Stoll 1983; Vickers 1984; Colby and Dennett 1994; Perkins 2004). However, briefly reviewing the history and reputation of the organization illuminates some of what's at stake in the complicated history of the IPC. William Cameron Townsend founded SIL. An innovator in his time whose unconventional ideas altered traditional fundamentalist approaches towards missions, "Uncle Cam" would later be described by peers as "a giant under God, one of the greatest leaders since Paul" (Colby and Dennett 1994, p. 820). When he moved to Latin America as a missionary in 1917, for his colleagues, he was already demonstrating "dangerous modernist traits, such as donning Indian clothes and showing an appreciation of Indian Culture" (Colby and Dennett 1994, p. 43).

\footnotetext{
${ }^{7}$ Rev. Frederick Gates in a letter to John D. Rockefeller, Sr., April 17, 1905; quoted in Collier and Horowitz 1976, p. 101.
} 
After more than a decade of living in Guatemala and working with the indigenous community, Townsend's ambitions had grown too large for the current style of missionary work in which he was involved. He saw the way indigenous communities were marginalized within the framework of dominant mestizo society, and believed this limited their ability to accept and be empowered by "the gospel." He envisioned a plan for autonomous, self-sufficient indigenous Christian communities to be accomplished using planes to find those tribes still unreached in the Amazon; he hoped to translate the Bible into each tribe's language, which, in true protestant ${ }^{8}$ fashion, eliminated any conception of a mediator between the individuals and God. At this time, missionaries had only translated into Spanish because they feared that indigenous communities with a Bible in their own language could not remain free from heresy that would necessarily result from their flawed interpretation (Stoll 1983, p. 36). Under this crucial auspice of linguistics research rather than evangelism, Townsend was granted access into previously closed countries, and tribal regions that had, until then, remained unreached by outside forces.

Since Wycliffe's beginnings in 1942, WBT/SIL personnel have been involved in the translation of 745 complete New Testaments and 27 complete Bibles, potentially impacting around 114 million people speaking 704 languages. ${ }^{9}$ The stated goal of SIL is to translate the Bible into all of the major languages and dialects of the world, based on

\footnotetext{
${ }^{8}$ Protestantism in many ways developed out of some Christians desire to forego any mediation between the believer and God, believing Jesus' resurrection and the rending of the veil described in Matthew (27:51) to be representative of God's desire to have direct relationships with human beings.

${ }^{9}$ Wycliffe International (Web)
} 
the belief that people who have access to the Scriptures in their own languages will experience revelatory truth. However, also abounding since Wycliffe's beginnings are consistent suspicions and accusations about the geopolitical nature of some of their affiliations and activities. Critics of the WBT/SIL have accused the organization, including their Jungle Aviation and Radio Service (JAARS), of espionage, genocide, and general promotion of U.S. imperialism (Vickers 1984, p. 200).

One of the most comprehensive investigations into these suspicions was produced by journalists Gerard Colby and Charlotte Dennett, who compiled and analyzed years of firsthand inquiry in their book The Will be Done, the conquest of the Amazon: Nelson Rockefeller and Evangelism in the Age of Oil. Their research is extensive, and the authors evidence both the ranges of extremes in judgments of SIL, while also acknowledging the probable:

In Colombia, criticism of SIL was particularly harsh, with charges ranging from the extreme (drug smuggling and uranium mining) to the serious (kidnapping Indian children and elders for extended fund-raising tours in the United States) to an approximation of reality (destroying the Indian's cultural values, creating religious divisions within Indian communities, deceiving the government about its evangelical goals, and indoctrinating Indians with loyalty to the United States). (Colby and Dennett 1994, p. 752)

Though this work is exhaustive, it pays particular attention to the convergence of interests and money between the Rockefeller oil and political establishments, and SIL. It is clear that the significant amount of both funding and political clout that enabled the group's activities were provided through the Rockefeller family and their subsidiaries. More troubling is establishing what "services" SIL provided in return.

Recently, John Perkins has extended the critique and claims of many indigenous and human rights leaders in Latin America about the purpose of SIL. Perkins claims to 
have been already familiar with SIL from his time in the Peace Corp. He recounts the following story:

SIL had been working extensively with the Huaorani tribe in the Amazon basin area, during the early years of oil exploration, when a disturbing pattern emerged. Whenever seismologists reported to corporate headquarters that a certain region had characteristics indicating a high probability of oil beneath the surface, SIL went in and encouraged the indigenous people to move from the land, onto missionary reservations; there they would receive free food, shelter, clothes, medical treatment, and missionary-style education. The condition was that they had to deed their lands to the oil companies. (Perkins 2004, p. 142)

SIL has issued a response which can be found on their website, maintaining, "the comments are based on rumors that have never been substantiated and are contrary to documented eyewitness accounts."

Despite the volume and intensity of accusations, ethnologist William T. Vickers expresses a more moderate interpretation of SIL's activity in Latin America. He states that a genuine understanding of the facts is made difficult by the plethora of charges made, many without any evidence, and affirms that polemics aimed at both defending and condemning SIL have done little to bring clarity. In a review praising David Stoll's history of WBT/SIL, Vickers does diagnose the least we can take away from the story of SIL:

The SIL is composed of people who see themselves primarily as Christians engaged in a mission of Bible translation. At the same time, most of them are Americans who have predominantly conservative political views and who see communism as a manifestation of the devil's work. The conspiracy theorists who believe that the SIL is a simple front for the CIA will find little support for their views in this book. It is true, however, that the SIL has influential ties to capitalist enterprise, politicians, and military figures in the United States and in the developing countries in which it works. ... The SIL is not an 'empire' per se, but foreign missions such as the SIL are part of the larger process in which powerful nations export political, economic, social, and ideological patterns to the relatively weaker and poorer regions of the world. (Vickers 1984, p. 201) 
While the story of SIL is unique, it also offers insights into the relationship between domination and proselytism. This history concerns missionary groups with ties to U.S.nationalist/capitalist policies and institutions aspiring to spread particular religious ideologies. What SIL's involvement in Latin America does illustrate is that while missionaries might preach what they believe to be transcendent good news, as contingent individuals their situatedness and multiple subject-positions embody a range of powerrelations, not the least of which relate to a history of imperial and colonial geopolitical conditions.

\section{THE HISTORY OF THE IPC}

Turning attention to the Presbyterian community in Colombia, little analysis exists on its history. Historian and theologian Javier Rodríguez, who is also the Church's National Moderator and Director of the Colegio Americano de Bogotá, has produced some of the only histories about the religious community's activity in Colombia. ${ }^{10}$ Francisco Ordoñez has focused extensively on the history of Christian evangelism in Colombia, and so has also recorded a substantial amount of early Presbyterian activity within the country. Nevertheless, interviews and observation with IPC leadership has demonstrated a strong familiarity among members with both the community's origins-

\footnotetext{
${ }^{10}$ The general history offered here is derived from a number of sources in addition to published material, including: interviews with Dr. Rodríguez conducted on July $21^{\text {st }} 2012$ in Itagüi, Antiochia, and August $8^{\text {th }} 2012$ in Bogotá; unpublished manuscripts and letters photocopied by permission of Dr. Rodríguez; and various other interviews with IPC leaders and members throughout July and August 2012, in and around Medellín, Bogotá and Barranquilla, Colombia. This chapter relies most heavily on Dr. Rodríguez compilation, as he has gathered an impressive array of primary documents when writing his dissertation on the history of the IPC. All documents and interviews are on file with the author.
} 
stories and the major events and figures involved in its historical development, suggesting a commitment to the remembering and re-telling of their experiences.

Despite being relatively small in number, ${ }^{11}$ the IPC is unique for a number of reasons which merit sustained consideration. First, Presbyterians were the first Protestants in the country, with missionaries arriving in 1856. Second, during a formative constitutional period, the Presbyterians remained the only Protestants until 1901. Third, among Protestant groups in Colombia, the Presbyterians remained the most significant group until well into the $60 \mathrm{~s}$.

In addition, the Presbyterians' commitment to education ensured that this community has been at the forefront of scholastic reform and innovation throughout the nation's history. The Colegio Americano for girls was one of the first of its kind in the region outside of the Catholic Church, and the Colegios introduced co-ed classrooms to the country. The Colegios from the beginning have been places where the Liberal elite sent their children in order to receive an exceptional education, and a long list of distinguished leaders, from Orlando Fals Borda to former president Enrique Olaya Herrera, have graduated from Colegio Americano. In addition, it was from meetings organized by IPC members that the first Protestant worker's unions in the country were organized. Later, during the 60s, the group "La Rosca de Investigación," comprised mainly of Presbyterian leaders, was a source of great liberatory influence throughout the nation and region. For all of this, coupled with the fact that the IPC continues to be one of the most steadfast advocates in the region for a more humane and just society, it is

\footnotetext{
${ }^{11}$ The estimate is that there are roughly 5,000 members of the Church, with an additional student population of around 13,000. (Rodríguez 1992, p. ii)
} 
surprising that more work hasn't been conducted into the origins and effects of this community.

Rodríguez tends to divide up the history of the IPC into two distinct periods. The first lasts from the church's founding in 1861 until approximately 1960, and the second from 1960 until now. He, like many others, sees Vatican II as signaling a fundamental shift for religious communities in Latin America about how to engage not only the political conflict but also other religious communities.

After Vatican II the emphasis of anti-Catholic preaching began to decrease. The shift also signaled a change in how many Catholics came to see Protestants, now more as a family member that had been separated. That transition has coalesced around other movements that are calling for a contextualized view of the conflicts in Colombia. It led to a decrease in the influence of missionaries in favor the rise of a national leadership for the Presbyterian Church. However, Rodríguez (1992) acknowledges that "on the other hand, some of the factors pointed out come from before 1960, and some of the characteristics from the first period endure to this day in some sectors of the [IPC]. So [the division] can’t be considered as anything but approximate" (Rodríguez 1992, p. 10).

\section{CHALLENGES OF THE EARLY PERIOD: 1850-1960}

Rodríguez (2004) has shown that the establishment of Protestantism in Colombia related directly to the conflict between the Conservative and Liberal political factions. Liberals, as representatives of the move to a more modern state, invited Protestant churches, the Presbyterians being first, to found communities in the country. The Liberals used the Presbyterians in this way to marginalize Conservative positions and the dominant Catholic Church within the national political infrastructure, making the 
entrance of the Presbyterian missionaries legible particularly within the context of the ideological struggle of the state. As Liberal positions have advocated for the free-market and strong internationalist policies, the Presbyterian missionaries would be immediately aligned with those forces within the country most amicable to capitalist expansion and foreign intervention. Although the hostility between the Catholics and Protestants in the country owed more to their socio-political positioning vis-á-vis the Conservative/Liberal contest than their respective ecclesiastical divergences, Presbyterians in the country have tended to represent this tension in terms of Catholic/Religious persecution due to the hegemony of the Catholic Church within the country.

Rodríguez (2004) further traces the religious lineage of the IPC, not from the European Protestants of Iberia, France or Germany, but rather from the Puritanical movements coming out of New England. The British Legion, in helping Bolivar launch the revolution, brought with it a wave of puritanical Protestants, such as the Presbyterian Colonel Fraser from Scotland, a hero of the legion that helped to introduce coffee to the region and later became the Minister of War after marrying one of General Santander's nieces (2004, p. 289-91). In a sense, Fraser was the preeminent, symbolic Protestant figure in Colombia after the revolution. Representative of imperial, capital interests, his commitment and support for the Liberal agenda allowed the Presbyterian missionaries access to the country that would be leveraged to combat the Conservative agenda. After Fraser became Minister of War and helped prevent the establishment of a National Church, he wrote the Presbyterian Church in Scotland to request missionaries. However, without funds or volunteers, the Scottish forwarded the letter to the U.S. Presbyterians. The response from the Board of Missions recorded in the Minutes of the General 
Assembly of the Presbyterian Church in the U.S.A. (1855) indicated a desire to send missionaries to Colombia (quoted in Rodríguez 2004, p. 291).

Rodríguez (1992) notes a multitude of distinctions for groups coming out of the puritanical lineage, as opposed to the established continental European Protestantism, including a particular emphasis on personal experience over institutional affiliation. It is also worth recalling Weber's estimation of the role of the protestant work ethic in forming strong, capitalist social formations, which would only reaffirm the socio-political role of the Presbyterians within the Liberal national agenda. Rodríguez also notes that because U.S. Protestantism had so many denominations, despite conflicts and disagreements between the sects themselves, there was generally more of a spirit of tolerance and collaboration among these groups than was seen, for example, from Catholic sectors toward other faith communities. Lastly, the development of a social gospel among U.S. Protestants would later influence the work of the Presbyterians in the country (Rodríguez 1992, p. 5-7). ${ }^{12}$

The first Presbyterian, and Protestant, missionary in Colombia was the Reverend Henry Barrington Pratt. Pratt arrived in Cartagena on March $17^{\text {th }}, 1856$, before getting to

\footnotetext{
${ }^{12}$ For example, “...el 'evangelio social', que pretendía fomentar la aplicación de las enseñanzas de Jesús y del mensaje total de salvación Cristiana a la sociedad, a la vida económica, a las instituciones sociales... así como a los individuos'. Las obras de Walter Rauschenbushc, historiador bautista, se tornaron clásicas. Dos ejemplos: Christianizing the Social Order (New York, McMillan, 1914) y The Social Principles of Jesus (New York, Association Press, 1916). Los títulos de algunos de sus capítulos son significativos: 'Una Religión para la redención Social', 'Qué queremos decir por Cristianización del orden social?', 'Nuestro presente orden económico' 'El reino del intermediario', 'Bajo la ley del lucro', 'Los valores morales del capitalismo: Lucro x vida, comercio x belleza', 'Cristianismo contra capitalismo', 'Conservación de la vida', 'Socialización de la propiedad', etc. ... En resumen: teología de la liberación del siglo XIX, activamente patrocinada e implementada por los sectores emocionales y piadosos de la iglesia." (Alves 1981, p. 127-8; quoted in Rodríguez 1992, p. 7)
} 
Bogotá on June $20^{\text {th }}$ (Rodríguez 2004, p. 293). His first worship service was conducted in in English at the Hotel Dickson with 10 foreigners and 2 Colombians. As more Colombians became interested in the services, they converted the services to Spanish, which brought sharp increases in attendance.

The next missionary was Reverent Tomás Wallace, who was placed in charge of the Bogotá project while Pratt travelled the country to evangelize and found new communities. When Pratt returned from his trip, a newly married missionary couple had joined the project, the Sharpes. Through their collaboration, the community began a night school for workers with classes on the Bible, writing and math (Ordoñez 1956, p. 28-32). Pratt, who had been educated in the Presbyterian Seminary at Princeton, soon decided the Reina Valera version of the bible was too archaic to be of use to the people, and began an ambitious project to produce a more contemporary translation, which is used to this day, the Versión Moderna (Brackenridge and Ordoñez 1974).

The community had early success despite habitual harassment on the part of the Catholic clerics, who would spy on members and make accusations of heresy and witchcraft. The relationship between the Catholic and Protestant churches in Colombia has always been tenuous, but, again, this was less on account of the substance of their theological differences and more to the socio-political contexts that positioned the churches. Catholicism and Protestantism were mechanisms of leverage within the larger struggle for power between the Conservative and Liberal factions in the country. As political actors in an escalating conflict, the Protestants and Catholics fed off one another in a growing cycle of harassment. Although, over time, the Presbyterian missionaries came to play an even more significant role with respect to the larger political struggles 
taking places between the Conservatives and Liberals after the war of Mil Días,

Rodríguez asserts that, initially, “estos misioneros no tenían tanto interés en combatir a la iglesia Católica, 'sino predicar contra el pecado para que los pecadores acudieran a Cristo"” (Rodríguez 1992, p. 12, in the end citing Ordoñez 1956, p. 30). However, Pratt became frustrated with the lack of spiritual vigor in the community, writing, "Almost all of the world trusts for their eternal salvation in rites and exterior ceremonies; among the youth and the most educated men, one doesn't see any interest for the Church, having fallen simply into some vague deism without a definite orientation" (quoted in Ordoñez 1956, p. 30).

As time went on, Pratt lobbied against the perceived spiritual malaise by writing pieces in El Tiempo, the voice of the Liberals, against the Pope and about the right to access Scripture for all believers. These writings would receive wide-acclaim and dissemination via Colonel Fraser, who used them as political tracts meant to delegitimize Conservative positions. This further ensconced the role of Protestants in general and Presbyterians in particular within the national political conflict (Rodríguez 2004, 294). On October $11^{\text {th }}, 1858$, Pratt wrote,

La escuela es definitivamente para artesanos. Desde el sábado en la mañana, he rechazado cinco aplicantes que no son de esta clase... Casi todos nuestros estudiantes están haciendo decididos progresos... Más de una vez se ha predicado contra nuestra escuela y los estudiantes dicen que ellos están fichados y temen. ${ }^{13}$ (quoted in Rodríguez 2004, p. 296)

Educational initiatives for the workers played an important role in the political conflict, as the Liberal establishment encouraged the Presbyterians to further develop these

\footnotetext{
${ }^{13}$ In another place, Rodríguez (1992) comments on this excerpt, noting its importance not only for the portrayal of religious thought in Colombia during the period, but also for revealing the religious conception of the missionary and the nature of his mission (p. 12).
} 
projects in order to combat the influence of similar Catholic initiatives being carried out by the Jesuits (Colmenares 1968, p. 176-177). The Reverend Alexander M. Allan commented on the hostility of the Catholic establishment towards Presbyterians, specifically in regards to educational initiatives:

La situación del alumno evangélico en las escuelas públicas es delicada, y a menudo se extrema más por la intransigencia del maestro, ya por la persecución sistemática y crueldad de los mismos niños. Las escuelas colombianas son para los niños colombianos, sea cual fuere su religión; pero sucede que en ellas es obligatorio para todos el asistir a la clase de religión, y si en ellas está reglamentada la asistencia en fila a la misa, es necesario también asistir.

Hasta allí todo es claro y patente, pero a menudo sucede que hay sacerdotes y maestros que pretenden obligar a los alumnos a confesarse y comulgar. ... Padres evangélicos: cuando sea posible, fundad vuestras propias escuelas; si no lo es, procurad enseñar a vuestros hijos en casa; y en último caso, si han de asistir a las escuelas públicas, por absoluta falta de otro medio, procuréis que de ninguna manera se confiesen y comulguen. (quoted in Rodríguez 1992, p. 17)

Rev. Sharpe insisted that the Board of Missions establish similar schools in Barranquilla, Medellín, Bucaramanga y Popayán, "lugares considerados estratégicos para un mayor cubrimiento de la misión evangelizadora" (Rodríguez 1992, p. 12). In July of 1860 Reverend Guillermo McLaren arrived with his spouse in Barranquilla. Around this same time Pratt returned to the U.S. in order to attend to multiple commitments he had awaiting him. When Sharpe travelled to receive the McLarens, however, he died of yellow fever, and so the Presbyterian movement that had been gaining momentum recently throughout the country, and in Bogotá in particular, was soon in danger of becoming irrelevant.

At the same time the country was plunged into Civil War by the uprising of liberal military officials led by General Tomás Cipriano de Mosquera to overthrow the Conservative President Mariano Ospina Rodríguez. Individuals and groups were sent into 
exile, including the Jesuits. On November 15, 1861, McLaren received a letter from the Dr. M.L. Lleras, Judge of the Supreme Court, which said

El señor Presidente [Mosquera) me ha pedido manifestar a Ud. sus deseos de que vengan al país más misioneros protestantes; y que deben establecerse Iglesias y escuelas protestantes en el país. Por otra parte, habiendo llegado a manos del gobierno varias propiedades antes pertenecientes a la iglesia católica, el Señor Presidente desea que algunos de tales edificios sean utilizados para los fines antes dichos. (Ordoñez 1956, p. 40)

This letter further demonstrates that the hostilities between the Catholics and the Protestants owed more to their socio-political positioning within the governmental conflict than the discrepancies between faiths. At the same time, all of this political jockeying taking place by the politicians, the seizing and transferring of properties, expulsions, etc. was generating genuine antipathy between the Catholics and the Protestants. Although Mosquera offered for the Presbyterians to hold their worship services in the old Jesuit convent, McLaren decided to postpone such a move until the government strove to promote Protestantism more consistently within the country (Ordoñez 1956, p. 40). The Presbyterians didn’t acquire their own property until 1868, which was strategically situated in the Dominican convent "donde funcionaba durante la Colonia la ‘Santa Inquisición”” (Rodríguez 1992, p. 13). Mosquera’s regime represented a significant persecution of the Catholic Church and led to resentment among large sections of the population towards the Protestants as the Liberals used them to gain ground in the cultural struggle for political supremacy.

Kate McFarren arrived in Bogotá in 1868 to work exclusively on the educational aspect of the Presbyterian community. Feeling mistreated and humiliated by people within the official institutions, Protestants desired their own place to study. In 1869 the 
Colegio Americano was created, beginning with 18 girls and few resources. The school soon grew though, requiring a larger space, and one of the ex-presidents entered his 2 daughters into the school, which furthered the Colegio's recognition and growth (Ordoñez 1956, p. 44).

The community continued to grow each year, as more missionaries were sent to help facilitate different aspects of the church, and as more missionaries came and left, the Colombian members worked to establish a national identity for their Presbyterian Church. In 1885 Tomás H. Candor created the Colegio for boys. In September of 1894, the missionaries convened their first national missionary meeting in Bogotá, with representatives from Bogotá, Medellín and Barranquilla, where together they developed plans for the future of the Church and their education initiatives (Rodríguez 1992, p. 14). Under Candor's direction, the Presbyterian community of Bogotá achieved high esteem. He was invited by the National University to be Rector on account of his innovative and expansive visions for educational reform, although he ultimately declined (Ordoñez 1956, p. 47-8).

However the growth of the Church was interrupted by the "Guerra de los Mil días" and the loss of Panama to the U.S. An intense anti-“yanqui" sentiment had been growing among the people and there were numerous threats to burn down the Colegios and the churches. The failure of the radical liberal regime also led to the conservative rise to power, which, united with the Catholics, led to a greater persecution of the Presbyterians. This annexation of Panama by the U.S., in addition to the dominance of U.S. corporate interests in the nation's oil and fruit industries, increasingly fomented public resentment towards the Presbyterians during this period. Although attendance at 
the school dropped dramatically during this time, by 1904 General Rafael Uribe Uribe, a congressman, enrolled his children in the Colegio, and other elites followed, once again raising the popularity of the schools (Rodríguez 1992, p. 15). In this way the Colegios continued to play an important political role, representing a safe space for Liberals during hostile times, especially during the Mil Días. ${ }^{14}$

In 1933 the U.S. Presbyterian Mission began to reduce its support for the IPC, as national leaders were becoming able to sustain their activities. The growth of the IPC was aided by the fact that the Liberal politician, Enrique Olaya Herrera, who had attended the Colegio Americano de Bogotá, was president from 1930-1934 and offered the Presbyterians ample support. By July of 1937, the Church had gradually grown enough to the point where they could orient themselves into the regional organizational model used by Presbyterian communities. The Presbyterian Church of Colombia became organized into 1 Synod, with 3 Presbyteries: the Coast, Central and the West. At this point, the hope was that the national leadership was in a position to begin to take more control of the church, as the role of the missionaries would become less essential to the operations of the established communities. However, such a transition would take a far more time to accomplish for the IPC.

Although the Presbyterians continued to have conflict with the Catholic and Conservatives forces owing to the national political climate, the Presbyterian community enjoyed growth and relative peace until 1946, which began the period of "La Violencia"

\footnotetext{
${ }^{14}$ In 1916, a conference was held in Panama, newly sectioned off by the U.S. Empire, about how to pursue the future of missions work in Latin America. One outcome of the meeting was a sharp increase in Protestant missionaries to the region in the following years. This move augmented the sensation for many of a growing North American capitalist imperialism and a lack of respect for local autonomies (Bidegain, interview).
} 
and the death of hundreds of thousands of people. After a period of Liberal control, Conservative politicians Ospino Pérez and Gómez Castro gained power, which brought about strong reactions from the more extreme wings of the Liberal party. Within such a climate the adored, populist figure Gaitan rose to prominence and his assassination was the spark that led to La Violencia. At this same time, the U.S. Secretary of State was in Bogotá to lead the $9^{\text {th }}$ International Conference of American States, which ended in a pledge by members to fight communism, and led to the creation of the Organization of American States (OAS). To the sharp and sectarian violence sweeping the nation at this time was now added the vitriolic categories endorsed by Cold War rhetoric. Whatever challenges had faced the IPC before were now exacerbated by the continued intervening presence of U.S. geopolitical interests and Cold War alliances (Loveman 2006).

According to James Goff, Conservative elements took advantage of the state of political affairs in order to attempt an extermination of Protestantism in Colombia at this time, although the extensive violence of the period was reciprocal:

Sacando ventaja del disturbio político y del estado de sitio declarado por el Gobierno, la Iglesia Católico Romana y el Partido Conservador juntaron sus esfuerzos para eliminar al Protestantismo. La policía fue adoctrinada a creer que los Protestantes eran agentes del comunismo; que ellos estaban conspirando contra el Gobierno Conservador; que ellos deshonraban a la Virgen María, al Papa y a la jerarquía; que ellos estaban introduciendo inmoralidad; y que ellos podrían dividir el país y destruir su unidad. Sacerdotes urgieron a la policía y a Católicos conservadores para hostigar y perseguir Protestantes y algunas veces lideraron a sus feligreses en ataques contra iglesias Protestantes, escuelas y casas. (quoted in Rodríguez 1992, p. 19)

During this period there were 2,406 documented acts of violence against the Protestants, 1,869 against people and 537 against property. The violence against people included arrests, confinement in prison, torture and forced labor, assassination, disappearances of 
families, and attacks during religious services. In addition, 60 churches and 166 houses were destroyed, with 89 Churches, 11 cemeteries, and 164 houses attacked and damaged (Rodríguez 1992, p. 19). Equally, there were massive acts of violence on the part of Liberals and Protestants against Conservatives and Catholics as groups struggled to gain dominance through force.

Because of the nature of the political conflict, the Presbyterian Church continued to have conflict with the hegemonic Catholic institutions, although the exact relationship to the conflict was often ambiguous. While some in the Presbytery advocated for preaching a message dedicated to overthrowing the Catholic institutional and ideological stronghold, as evidenced by the aforementioned publications of Pratt, others within the Presbytery endeavored to proceed in ways that didn't react to the conflict with the Conservative faction. A.R. Miles, a Presbyterian missionary, was asked, "Debemos entender, pues, que su propósito es el de convertir católico-romanos en presbiterianos?" He responded:

...Si por mis débiles esfuerzos alguno recibe el mensaje y acepta a Jesucristo como su Salvador personal y, mediante la gracia divina trata de arreglar su vida de acuerdo con los sanos preceptos del divino Maestro, poco y nada me importará el nombre eclesiástico con que se designe; será verdadero Cristiano, que es lo único que importa. (quoted in Rodriquez 1992, p. 21)

The Presbyterian Church, along with Christian movements at large, continued to struggle over how to appropriately respond to and engage the larger context of conflict and violence. Rodríguez (1992) adroitly notes that the ecclesial principle of avoiding interaction with the political conflict has often been based in the scriptural principle, "Give to Caesar what is Caesar and to God what is God's." This message was also exploited by political figures as an apologetic for the status quo. El Evangelista Cristiana 
has been an incredibly influential journal for the Presbyterians, at least until the $60 \mathrm{~s}$, and the following editorial illustrates the ambiguity and tentativeness about involving the

Church in the conflict:

Creemos que los miembros de las iglesias evangélicas deben interesarse en la situación política y concurrir a las urnas, pero que deben guardar bien el corazón, para que no entre el odio, y sobre todo que deben dejar su política el portó de la capilla.

Expresa bien nuestras ideas el señor A. Redondo, de Cartagena, así: ... 'Pagad pues al César lo que es del César y a Dios lo que es de Dios' (Mateo 22). ... Así piensan los que amalgaman la religión con la política pero verdaderamente se necesita tener una miopía intelectual muy grande o una corrupción de corazón extremada, para reducir que en aquella ocasión incidental, proclamó Cristo un principio que debía transformar la sociedad. Claramente distingue dos dominios y dos poderes. Dios, dueño de la conciencias; y César dueño de las cosas temporales. (quoted in Rodríguez 1992, p. 24-5; emphasis in original)

Another article in the same issues continues,

Los misioneros protestantes más avisados por la experiencia y más obedientes a las enseñanzas de Cristo, se guardan muy bien de mezclar la religión con la política, con lo cual consiguen no sólo formar virtuosas congregaciones cristianas sino también fieles ciudadanos. (Rodríguez 1992, p. 25)

Yet the impossibility of being neutral prevailed as a few days after the articles mentioned above were published, the journal Conciliación accused the Evangelista of being an ultraLiberal journal. In reality, Conciliación was right, because the Evangelista did openly advocate for the policies of liberalism such as religious tolerance and the separate of Church and State, especially in the cases of marital law and education (Rodríguez 1992, p. 26). Sinclair (1981) describes the impossible attempt of Protestant groups in Colombia to maintain neutrality:

La Iglesia protestante se veía a sí misma como un grupo marginado de los destinos nacionales. Era una subcultura, alejada de la herencia nacional, y que no participaba en las aspiraciones de una sociedad cambiada según los ideales cristianos. Estaba en parte acomplejada por los nexos extranjeros, los ideales 
anglosajones y la 'huelga social' (no compromiso con los problemas sociales) de las tradiciones evangélicas norteamericanas.

La mayoría de los misioneros extranjeros tenían que prometer al abstenerse de participar en la vida política colombiana, de modo que se dejó la impresión de que el proceso político estaba fuera de la preocupación legítima del Cristiano y de que los poderes de este mundo son malos o por lo menos sospechosos. (p. 590)

This ambiguity reflected back onto larger global debates of imperialism and progress. Rodríguez points out that Protestants in Colombia had to occupy two separate poles with regards to the role of the U.S. in the world. On the one hand, the missionaries come from the U.S., bringing their own "cultural baggage," and the U.S. was then often presented as a model for democracy, as a defender of Colombia and as a proof for the Protestant ideals. Protestantism in Latin America has been consistently associated with the United States. Nevertheless, in order to have any credibility at all, the Protestants also had to recognize the imperialist attitude and activity of the U.S. with regards to Colombia and the so-called "third world":

Ese imperialismo no se podía ocultar en vista del rapto del Canal de Panamá, de los intereses voraces en el petróleo Colombiano y de la explotación de los trabajadores de compañas como la United Fruit, la cual provocó la huelga de los obreros que desembocó en los dolorosos sucesos de la "masacre de las bananeras."

Cuando reconoce el imperialismo norteamericano, se tiene cuidado de resguardar la imagen de las iglesias evangélicas del Norte y de aquí, manifestando que estas han luchado por defender los intereses latinoamericanos en el Norte y que sienten vergüenza y protestan cada vez que se tienen noticias de los abusos del imperialismo. (Rodríguez 1992, 31)

The shifts that began to take place around this time brought significant rupture to

the IPC. The unavoidable need for dramatic social change, not just in Colombia but also in many parts of the world, meant a reconsideration of the dominant logic of social

\footnotetext{
15 The massacre of laborers famously depicted in Garcia Marquez's 1967 work, Cien Años de Soledad.
} 
change previously being employed. In the IPC, from the time of the missionaries, through to the $60 \mathrm{~s}$, the logic of social change has been, 'Convert the individual and the society will transform.' Rodríguez (1992) claims that at the time the proposal for social change through personal transformation arrived in Colombia with the missionaries, it did represent a subversive alternative to traditional, or "señorial," society that had predominated in Colombia. He sees that original proposal for social change as bringing values such as liberty, public education, representative democracy and economic liberalism to a country at the turn of the $19^{\text {th }}$ century that had long been repressive and intolerant (1992, p. 32). José Miguez Bonino (1985) concurs: "El protestantismo ayuda a crear, de esta manera—en un ámbito y número muy limitado por cierto—personas funcionales a un cambio de estructura social y de mentalidad en América Latina” (p. 21).

Nevertheless, amid changing conditions such logic became a defense of the status quo. Whereas education, temperance, initiative, etc. were progressive values before, an exclusive focus on these values as the motor for social transformation began to foreclose more fundamental critiques about the systemic nature of the society being created. A pivotal example of the transition from prior logics of social transformation to new ones can be seen in the arrival of Richard Shaull in $1942 .{ }^{16}$

Even today, leaders of the IPC bring him up often, using his name when talking about the radicalizing forces that have altered the trajectory of their community. Shaull

\footnotetext{
${ }^{16}$ It may seem problematic to talk so much about the role of missionaries in the life of the IPC, but Rodríguez follows Alves (1981) in cautioning such an assumption: "Ligar el movimiento misionero, pura y simplemente a la expansión imperialista, es transformarlo en un cínico apéndice de intereses económicos" (p. 183). For the other view of missionary activity in the region see Gerard Colby and Charlotte Dennett. Thy Will Be Done: The Conquest of the Amazon : Nelson Rockefeller and Evangelism in the Age of Oil. New York, NY: HarperCollins, 1995.
} 
was a major influence upon Orlando Fals Borda, among others. His work is, in fact, enjoying a resurgence ${ }^{17}$ among radical and contextual theologians as they've begun to track his influence upon prominent Liberation Theologians. ${ }^{18}$

Shaull was unlike previous missionaries in that he brought an edge and a critical disposition to the socio-political context, which had been previously absent. According to Santiago-Vendrell (2010), "Shaull was one of the first Presbyterian missionaries after WWII who made the social, political, and cultural revolution of his time the fundamental theme of the theological reflection" (p. 4). He points out that before Gutierrez called for the primacy of praxis in the 70s, Shaull was inviting Presbyterians communities throughout Latin America in the 1950s into a revolutionary engagement with praxis:

Our starting point must be in praxis, but praxis of a very special sort: our own experience of exodus and exile as we break out of the order of social oppression and personal repression of which we are victims, and move expectantly toward a new land of promise, toward the creation of a new order of social and personal existence. (Shaull, quoted in Santiago-Vendrell 2010, p. 7).

Ultimately, Shaull has been one of most important Presbyterian missionaries and theologians to date.

He studied sociology at Elizabeth College in Pennsylvania before moving on to the Princeton Theological Seminary, where he graduated in 1941. When he arrived in

${ }^{17}$ See for example: Santiago-Vendrell, Angel D. Contextual Theology and Revolutionary Transformation in Latin America: The Missiology of M. Richard Shaull. Eugene, OR: Pickwick Publications, 2010; and Roldán, Alberto F. "La teología contextual de Richard Shaull: del paradigma de la revolución al paradigma de la liberación." Teología y cultura. Vol. 13 (November 2011): p. 27-47.

${ }^{18}$ This period also begins to sharpen an already happening bifurcation among priests and theologians worldwide, between conservatives and progressives, especially with regards to the issues of capitalism and imperialism. At each level of response, the groups grew further apart. Shaull is a preeminent and first example of the rise of the progressive theologian, and unique for being a North American missionary, at that. 
Barranquilla in ' 42 he began a definitive process of transformation and challenge within

himself. While he would later do some of his most substantial work in Brazil, his years in

Colombia were formative in the development of his revolutionary theology. In a letter to

Rodríguez, he writes:

Cuando llegué a Colombia en 1942, encontré una Iglesia Presbiteriana pequeña y débil. ... En general, los misioneros y líderes nacionales daban, a la iglesia, una orientación bastante conservadora, en lo teológico y lo social. Al mismo tiempo había un buen número de personas, especialmente de jóvenes, que estaban buscando una orientación más progresista y estaban dispuestos a servir a otros. ...traté de estimular un tipo de predicación más relacionada con la vida y los problemas del pueblo... y también me esforcé para despertar mayor interés en los problemas de la comunidad, y en servicio a los necesitados, trabajos de alfabetización, contactos con obreros en la industria, etc.... Cuando estábamos viviendo en Barranquilla, mi esposa y yo decidimos ir a vivir en un barrio pobre (que escandalizó a algunos de los misioneros), donde empecé un trabajo con miembros de iglesias evangélicas que trabajaban en la industria, entrando en contactos con sindicatos, etc. En mis sermones y mi trabajo con los jóvenes, siempre enfatizaban las dimensiones sociales del Evangelio y la vocación de los Cristianos en la transformación de la sociedad. Recuerdo muchas discusiones y conflicto por que insistía que los Protestantes, para luchar por la justicia, tendrían que estar participando activamente en la política.... Y en Bogotá, como ya dije, tuve contacto con estudiantes marxistas y empecé a estudiar el Marxismo y preocuparme por la relación entre fe cristiana y marxismo. Yo creo que los años en Colombia me ayudaron mucho a empezar a hacer un análisis del funcionamiento de estructuras sociales y económicas y también a ver claramente la necesidad de una teología que me sirviera mejor para enfrentar esta realidad. (A letter from Shaull written to leaders of the IPC in January of $1992^{19}$; quoted in Rodríguez 1992, p. 34-5)

In Colombia, Shaull realized the limit of the old logic of transformation, coming to understand that only fundamental movement on the structural level could improve the lives of people suffering (Shaull 1985, p. 186-7). As Rodríguez (1992) points out, Christians at all times would have agreed that the ultimate cause of the social crises of the age is sin, only now there was a movement to acknowledge not simply personal sin but

${ }^{19}$ All other Shaull citations drawn from Rodríguez, unless otherwise noted, come from this personal correspondence between the two in January of ' 92 . 
historical and structural sin as well that prevented people from flourishing and thriving (p. 31-32).

As Shaull underwent a radical change from his previous approaches to social transformation, he increasingly linked with groups from the poorest areas. In Barranquilla, Shaull encountered a child in one of the poorest neighborhoods who took an interest in learning to read. Shaull and the child met together regularly for a period of time until the boy was able to read with little difficulty on his own. However, once the boy had learned how to read, they continued meeting. Shaull worked with the boy to teach how to teach others to read, and helped him to set up weekly classes so that he could work with his peers. The missionary gathered books from his own collection and other places, helping the boy to start a community library out of his yard. Soon Shaull was able to detach totally from the situation and a full community educational initiative was being run by a 12 year old out of his yard. These reading lessons over time became organizing initiatives in which members of the community would discuss ways to improve the conditions of their labor and brainstorm about how to resolve local problems plaguing the neighborhood. The young boy who was at the heart of Shaull's initial attention and led the later initiative went on to Seminary in Medellín before returning to Barranquilla where he became a leader of the Presbyterian Church where he's been involved with numerous projects between the IPC and the local city government. ${ }^{20}$

According to Shaull, there have been two kinds of missionaries in Colombia: evangelists and educators. The educators were generally more liberal politically and socially, but this isn't to say that those focused on evangelism didn't invest a great deal of

${ }^{20}$ This anecdote has been repeated to me during various interviews. 
energy into social projects. But while the vast majority of missionaries were unable to relate to Latin American mentalities and cultures, in addition to the vast social and economic differences, Shaull has been often referred to as an exception. Shaull seemed to understand some of the problematic elements and power disparities involved in the missionary model. His reflection about the problematics of the missionary model within the IPC is incisive and telling:

... yo me identificaba mucho más con los otros Colombianos con que estaba trabajando que con otros norteamericanos. Yo estaba convencido de que nosotros, los misioneros, habían llevado a Colombia un Protestantismo importadodoctrina, liturgia, himnos, estructura eclesiástica, estilo de vida, etc. Y también toda una mentalidad de clase media. (quoted in Rodríguez 1992, p. 65).

Because the relationship between the missionaries and the nationals has been fundamentally one of power imbalance, it's been continually one of conflict, separation and re-approach as groups have sought to be honest about the very real power disparities between the Colombian communities and U.S. citizens. When the Presbyterian Mission began reducing support, Colombian pastors expressed concern about the ability of local congregations to offer sufficient support for the pastor to survive. The responses of the Mission were often simplistic and didn't respond adequately to the problem, answering issues of salary with, "The salary of the pastor should be in accord with the capacity of the Church," regardless of what that meant for the pastor (Rodríguez 1992, p. 56). In 1941, Dr. John R. Mott, president of the International Council of Evangelical Missions, came to visit Barranquilla. The Reverend Sebastian Barrios asked the Doctor about the problem, saying, "El problema no es solo escoger pastores y prepararlos, sino también garantizarles un sostén adecuado.” In addition, Barrios pointed out the added difficulty that the IPC needed to multiply the number of national preachers, as they were more 
capable of reaching and relating to the Colombian people than the foreign missionaries.

Dr. Mott's response illustrates the type of disconnect and unreality with which many U.S. workers approached the Colombian context: "El Dr. Mott respondió que la necesidad de más obreros nacionales y de su sostén era un solo problema y que su solución era aumentar el espíritu de sacrificio y de consagración de las congregaciones” (Rodríguez 1992, p. 57). Sinclair has expounded on the situation, writing,

Se notaba, hasta hace pocos años, un abismo entre la preparación de los pastores nacionales y los pastores extranjeros. Las diferencias de sueldos y garantías entre los pastores nacionales y extranjeros causaban una serie de tensiones, principalmente de carácter cultural, pero estas tensiones se combinaban con la gran diferencia en preparación académica y teológica lo que provocaba mucho distanciamiento. (Sinclair 1981, p. 664)

This also made it difficult of course for the IPC to achieve true autonomy, which they'd technically had since they organized into a Synod in 1937. Shaull described the period when he arrived to the IPC as "controlada por los misioneros" (Rodríguez 1992, p. 58).

Yet by the 50s, the Mission ceased to exist and the IPC was directing the subsequent activity of the missionaries that came. However, this more genuine autonomy did not mean that the Church's financial capacity for self-sustenance had changed. The IPC was in transition, and so was the region.

\section{REFORMAR Y REFORMARSE: 1960-PRESENT}

It is customary to blame secular science and anti-religious philosophy for the eclipse of religion in modern society. It would be more honest to blame religion for its own defeats. Religion declined not because it was refuted, but because it became irrelevant, dull, oppressive, insipid. When faith is completely replaced by creed, worship by discipline, love by habit; when the crisis of today is ignored because of the splendor of the past; when faith becomes an heirloom rather than a living fountain; when religion speaks only in the name of authority rather than with the voice of compassion--its message becomes meaningless. ${ }^{21}$

${ }^{21}$ Heschel 1955, p. 3 
By 1959, the only Presbyterian institution functioning in the country was the IPC - that is to say, the U.S. Presbyterians had no more intention to facilitate a Presbyterian Church in Colombia. The missionary workers now operated at the discretion of the IPC. The country itself was in a time of turmoil, enduring the brutal period of $L a$ Violencia, which ultimately led to the power-sharing structure known as the Frente Nacional. At large, the repercussions of U.S. involvement in the overthrow of the Guatemalan democratically elected president and the subsequent revolution in Cuba were fundamentally altering political assumptions about the future of the region, while reorienting ideas about economic development and self-determination. Amid this reimagining and re-structuring of how to relate to the future, progress, and justice, the IPC, along with the Christian Church at large, was beginning to reassess its relationship to the social and political context of the era.

The changes that took place at Vatican II surprised many people, and not just the laity. After years of emphasizing a message of present status quo and desires for another world, the hierarchy in Colombia was not ready to suddenly struggle in the name of religious liberty. Fernán Gonzalez writes, "Varios obispos y teólogos llegaron hasta confesar que les habían 'desencuadernado' su manuales de teología; muchos aceptaron de manera superficial los nuevos enfoques" (Gonzales 1989, p. 388). While among the most significant shifts that the Council brought were the dynamic changes in relations between clergy and laity and changes in relations between Catholics and Protestants, some felt that the Council didn't go far enough in offering clear directives concerning the situation of poverty and hunger in Latin America, which led to the Medellín conference in 1968. 
Just before the conference, however, the priest Camilo Torres had been making an impact in Colombia. As a young priest in Colombia, Torres caused a significant stir within the National Piety as he challenged the Church leaders to make a bolder commitment to the struggle of the people. Eventually a challenging, private letter from himself to the leaders was obtained and published in Bogotá, leading the leadership to demote Torres. Camilo insisted that Matthew 5:23-24 ("If you bring your gift to the altar and there remember that your brother or sister has something against you, leave there your gift at the front of the altar, and go, reconcile first with the brother or sister and then come and offer your gift.") applied to the relationship between religious figures in the nation and the vulnerable communities of the country side: "Para Camilo esto quería decir que hay que ir a reconciliarse con el hermano que es el pueblo explotado y ofendido por siglos" (Benavides y Castillo-Cárdenas 2010, p. 16). Together with Eduardo Umaña Luna and Orlando Fals Borda, he founded the Faculty of Sociology at the Universidad Nacional. He was also an advisor for INCORA (Instituto Colombiano de Reforma Agraria). Alonso Ojeda wrote about his experience working Camilo:

De esa tarde [22 de Mayo de 1965] al 15 de Febrero de 1966 no hay ni siquiera un año; en ese lapso sacudió, movió, traqueteó toda la estructura carcomida de este sistema e impactó a todos los Colombianos. Lo de Camilo era impresionante, una persona sin respaldo político de ninguna clase, sin ayuda económica, concitaba amplias multitudes llevando su mensaje. Esto se explica por la personalidad del cura y por las características de nuestro pueblo, tan católico, al que impresionó que de pronto apareciera un sacerdote diciendo que existe la posibilidad de hacer la revolución sin que fuera comunista ni se ganara la excomunión, ni tuviera que ser ateo; en otras palabras, crea un nuevo estilo y una nueva posibilidad política. (quoted in Rodriquez 1992, 70)

Torres had an uncompromising dream to unite the Left in Colombia and struggle with the people. However, he eventually grew exasperated with the divisive climate of leftist 
groups, and ultimately decided to join the guerrilla fighters of the ELN. Torres died fighting in Patio Cemento (Santander) on February 15, 1966 (Ocampo Lopez, 1972, p. 22-38). Yet when the Pope visited Colombia in August of '68, he reminded the people that "La violencia no es Cristiana ni evangélica," which some took to represent a support for the status quo (Rodríguez 1992, p. 71).

Despite these conflicts, when the Latin American Episcopal Conference, CELAM II, met in Medellín later that year, there was an attempt to translate the intentions of Vatican II into the Latin American reality. Where Vatican II hadn't practically applied the gospel message of liberation and solidarity for those suffering in the region, these leaders intended to do just that. Much of the work which Shaull had been involved in for a number of years already was proposed, with Ecclesial Base Communities and the importance of Liberation Theology emerging. Catholic Action and the Base Communities gained important traction afterwards. However, there was much disagreement, and some felt like it went too far, especially among Colombian hierarchy; for example the leadership of the Catholic Church in Colombia had a strong reaction to the following statement by a group of Colombian priests named Grupo Golconda:

La enérgica reprobación que hacemos del capitalismo neocolonial, incapaz de solucionar los agudos problemas que aquejan a nuestro pueblo, nos lleva a orientar nuestras acciones y esfuerzos con miras a lograr la instauración de una organización de la sociedad de tipo socialista, que permita la eliminación de todas las formas de explotación del hombre por el hombre y que responda a las tendencias históricas de nuestro tiempo y a la idiosincrasia del hombre colombiano. (quoted in Rodríguez 1992, p. 73)

The result was that those involved were persecuted.

El Jueves 16 de Octubre fueron puestos presos en Medellín, Colombia, cuatro de los principales sacerdotes del grupo GOLCONGDA. Su crimen: el de practicar un cristianismo comprometido con la causa de los pobres, siguiendo las enseñanzas 
del Congreso Episcopal Latinoamericano (CELAM), reunido el año pasado, con la presencia del Papa, en la misma ciudad de Medellín. Los cuatro curas han sido arrestados arbitrariamente incomunicados, golpeados con bolillos por la policía, condenados a treinta días de cárcel, sin la posibilidad de defenderse por la vía legal, ya que los abogados encargados de la defensa han sido hostilizados y finalmente encarcelados por 48 horas. Todo esto ha sucedido con la complicidad evidente de la alta jerarquía eclesiástica. (Castillo Cárdenas 1969, p. 87)

Nevertheless, and despite the many pushbacks by certain elements of the Catholic

hierarchy, what had happened in Medellín had expressed a deepening and irrepressible sense of commitment to justice that was sweeping the region.

In 1959 in Sao Paulo, the $18^{\text {th }}$ General Assembly of the World Alliance of

Reformed and Presbyterian churches gathered to discuss the changing world context.

Richard Shaull, among others, was in attendance. Many of the affirmations that came out

of the General Assembly mirrored what would come out of Vatican II and Medellín:

- Que la Iglesia esta frente a una situación nueva la cual no tiene precedentes.

- Que la Iglesia no puede ser un fin en sí mismo, sino que debe server al propósito de Jesucristo en el mundo.

- Que la Iglesia esta aislada del mundo en vez de encarnada en el.

- Que la congregación local corre el peligro de convertirse en un grupo cerrado en el cual otros no puedan entrar fácilmente.

- Que a veces es vista cómo un supermercado ofreciendo satisfacer todo tipo de necesidades del hombre moderno, en lugar de llamar a los hombres a participar dinámicamente en la obra de Dios en el mundo. Se cuestiona su lenguaje, su manera de vida, sus programas los cuales parecen estar en competición con otros grupos. La Iglesia es un grupo autocentrado.

- Que, a la luz de la crucifixión de Jesús, la Iglesia debe confesar su falta de solidaridad con el mundo.

- Que ella ha tratado, muy frecuentemente, de mantener su lugar en la sociedad antes que darse al mundo en servicio sacrificial y que la Iglesia ha sido indiferente a la dinámica socio-política y a los movimientos culturales que se han levantado en el mundo moderno.

- Que, a despecho de su aislamiento, ella no está libre con respecto al mundo, y es antes una Iglesia del mundo que una Iglesia en el mundo. Se busca, pues, una renovación de la Iglesia y sale a toná nuevamente el lema: "ecclesia reformata semper reformanda". (quoted in Rodríguez 1992, p. 76) 
In '63, the Presbyterian Church met in Bogotá to review the nature and mission of the Church in Latin America, focusing on the lack of theological training in the region. Later, in June of '64, a pivotal meeting in the IPC history took place between The Commission on Ecumenical Mission and Relations (COEMAR), the PC(USA) (the U.S. Presbyterian branch that had always been involved in Colombia) and the IPC. COEMAR was essentially the branch of the PC(USA) which had facilitated their engagement with the IPC. After reflecting on the rapidly changing social, economic and political context of the country and the various struggles of the Church, they concluded: "Este Nuevo aproximamiento esta basado en el reconocimiento de nuestros mutuos esfuerzos en el pasado, y aún hoy es necesaria una nueva formulación de estrategias para las diferentes fronteras las cuales la iglesia debería estar enfrentando hoy" (Rodríguez 1992, p. 77).

The focus of this meeting, as it was in others, was on the need for the IPC to achieve true autonomy, while also needing to find economic resources to develop their mission. The goal had been for quite some time that the IPC would be strong enough to stand on its own, that it would be able to gather an indigenous momentum quite apart from any outside forces. Yet the strong catholicity of the nation, the perpetual social upheaval and violence, the longstanding inequalities, and the enduring presence of the North Americans continued to impede the development of a strong national movement. The leaders believed that a more adequate training of national leaders was the way forward to meet these goals, and so there was again a focus on the possibility of planning a theological center that could prepare both ministers and laity. The areas that they hoped to improve through such an initiative were: "Educación, Acción Social, (servicio a la comunidad, asistencia de victimas de la violencia civil, etc.), Evangelismo, (entre 
movimientos obreros, entre grupos profesionales y en las áreas marginadas de las ciudades), Contacto con otras confesiones religiosas y Comunicación (a través de la prensa, radio, literatura, etc.)” (Rodríguez 1992, p. 78).

During this period of changing relations between the IPC and the PC(USA), the purpose and role of missionary activity, now called "fraternal workers," had been questioned and was highlighted during the meeting. National leaders in the IPC agreed that the purpose of fraternal workers should be to strengthen the autonomy of the Church and the process of "indigenización" for the commitment to their mission, and that their distribution in the different presbyteries should be done in such a way that will not diminish the autonomy or identity of the IPC. The concluding confession of the council is telling, and shows the significant awareness and will of those involved to adjust to the changing conditions and consciousness of the country and Church:

Reconociendo que factores formativos en la historia nos han dejado con un complejo de inferioridad y un sentimiento de inseguridad, creemos que es necesario abandonar la postura antigua y asumir una nueva actitud de identificación con el destino de la nación.

Reconocemos que el rostro tradicional de la Iglesia fue identificado con un lugar de refugio, una fuente de confort y de caridad para unos pocos, más bien que un lugar de disciplina, una fuente de servicio, una escuela de entrenamiento y un almacén de beneficios espirituales y materiales para aquellos que están fuera de la iglesia.

La Iglesia es el Cuerpo de Cristo, la sociedad de los regenerados y llamados los cuales deben hacer encarnar la voluntad de Dios en la comunidad. La Iglesia no debe limitarse a sí misma para ser únicamente un canal para que otros reciban la divina gracia; es una luz en medio de la obscuridad, sal en medio de la descomposición, y un medio a través del cual el Espíritu enriquece la sociedad. La Iglesia ofrece su servicio sin esperar una alabanza terrenal, sino únicamente en gozosa obediencia a Dios. (quoted in Rodríguez 1992, p. 78)

While the IPC, like other Christian communities of the time, wasn't unanimously in favor of these transitions, some vocal leaders arose to voice the need for change. 
Three particular examples demonstrate the strain and strength of leaders in the Presbyterian community to call for a radical transformation and participation with the socio-political context of the country. In "El Desafío de la Civilización Moderna," Orlando Fals Borda $\left(1968^{22}\right)$, described the internal struggles taking place within Christian communities. Despite the significant scientific and social changes sweeping the world, the Church confused identification with the eternal with remaining static, he thought. The Christian Church had survived for two thousand years, not because it had remained stolid but because it had adapted to critics and the changing historical context. "Estas son las cargas pesadas del proceso, actuando como contrapeso en la transformación social, y su misión se reduce, muchas veces, a resistir dogmáticamente y a tornar la vida más llena de azares y conflictos de lo que sería necesario.” This was the reason that so many had to rebel from the Church, he wrote:

Por los motivos aquí expuestos, por el conocimiento que adquirieron, por su experiencia personal, por la descubierta personal de las injusticias sociales y económicas que se ocultan, a veces, bajo el manto de la religiosidad y de la caridad mal comprendida, no pueden más soportar la contemporización y la pasividad estática, que caracterizan a las iglesias atrasadas. Y son justamente estos sacerdotes y ministros los visionarios que logran el milagro de mantener viva la Iglesia, de inducirla a renovar los músculos atrofiados por los años de rutina y de insensibilidad social. (Fals Borda 1968, p. 61)

Around the same time Gonzalo Castillo Cárdenas, then an IPC minister, wrote an article entitled "Los Cristianos y la Lucha por un Nuevo Orden Social en América Latina" (1966). He asked, “¿En que medida su manera de vivir, su misión, su organización y las formas de su ministerio no son sino un aspecto más de la imposición extranjera, sin que su contenido se aplique o se asimile a las condiciones particulares de los países de

${ }^{22}$ Originally published on July $30^{\text {th }} 1965$ 
América Latina?" His next question reveals the changing discourse about the Church's relations with the Global North. “¿Es posible suscitar una renovación de la Iglesia en base a una 'nueva orientación' proveniente de Nueva York, o de Ginebra, o de Alemania? ¿No sería ello simplemente prolongar el mismo y antiguo colonialismo ideológico?” (1966, p. 84). He goes to highlight the tension in the Church of those who feel pressed to respond to the socio-political context and the status quo of the establishment:

Se constata en el protestantismo un endurecimiento institucional que, en otro tiempo, era característico del catolicismo romano solamente. Las instituciones religiosas parecen dispuestas a castigar, excluir y condenar abiertamente a aquellos elementos que por razones de conciencia, toman posiciones que no concuerdan con los intereses religiosos o eclesiásticos en el plano de lo social, de lo económico o de lo político. Los casos se multiplican en todo el continente y en casi todas las denominaciones. La lista de los pastores que han debido dejar su cargo, o que han sido forzados a dejar el país en virtud de que su iglesia no los sostenía más, es impresionante. (p. 89)

His argument focuses on the building tensions between the Church and the social order, between the impulse toward individualism and consumerism and the pressing need for social solidarity, between those who respected the social and political institutions and believed in their ability to create gradual change: "Pero también existen pastores y laicos que están convencidos que el interés de Dios se concentra sobre el bienestar del hombre en las situaciones concretas, que el orden establecido en muchos países es una afrenta a Dios, en razón de que es una afrenta hecha al hombre" (p. 91).

Castillo Cárdenas concludes by affirming that the revolutionary vocation of Christian inspiration in Latin America can provide unique values and resources to revolutionary movements in general. For example, the strong sense of fraternity characteristic in Christian communities gives cohesion to movements. Also the presence 
of generally agreed upon moral/ethical commitments allow for actions and sacrifices based in transcendent convictions as seen in the Martyr Theology of early Christianity.

The third and most evocative example of the changing tide in the community can be seen in a letter written by Jaime Ahumada in September 1968. During the period 1964-1965 an office was formed, the Concilio Colombiano de Obreros Fraternales (CCROF), that was supposed to help to facilitate the relationship between the Colombian Church and the fraternal workers who operated through COEMAR, the group facilitating the international operation of the PC(USA) e.g. the sending of the fraternal workers. The idea was that the CCROF workers would handle conflicts that arose between de facto missionaries and everyone else in the country. Jaime J. Ahumada was the chief administrator of this office, the president of CCROF, and he penned the letter to be considered below. Describing the goals of CCROF after 3 years, he declares that the objectives of the experiment has been to

serve as a guide and a point of contact for the fraternal workers, to collaborate in the study and transmission of requests for new workers for the national effort, to evaluate together with the responsible commissions the activities of fraternal workers, to collaborate with the representative of the COEMAR in the search for better understanding between nationals and fraternal workers, to promote studies, retreats, and other kinds of activities which will draw the two groups closer together and lead to a better understanding of the situation in Colombia. ${ }^{23}$

This report was submitted to COEMAR in the last days of September, 1968. In it, Jaime, after almost 3 years of working to facilitate the relationship "between nationals and

${ }^{23}$ translated by James Goff, REPORT TO THE DELEGATES TO THE CONSULTATION BETWEEN THE PRESBYTERIAN CHURCH OF COLOMBIA AND THE COEMAR; SEPTEMBER 25-28, 1968. See Appendix in Rodríguez 1992. Copy is on record with the author. 
fraternal workers," argued that the current relationship was untenable and no longer relevant to the needs of the nationals.

Ahumada called for the decolonialization of relations between the IPC and their U.S. counterparts. No longer willing or desirous that the fundamental and unaddressed colonial relations that predominated, if facilitated, the presence of the North Americans with the IPC should continue, the report is a call for a transformation of relations.

Ahumada begins with a straightforward rejection of the long-standing inequality of power between the communities.

Nevertheless, I think that the work of CCROF at the present time should take a new route. In the light of the new events in the world, in Latin America, and especially in Colombia... the place of the Protestant Christian Church is presently very far from being adequate for a true testimony of Christ, the Lord of History, who manifests himself in the continual explosions of inconformity which shake our world. And the well-intentioned missionary work carried out by Protestant Church agencies of the United States, a work which initially produced beneficent results even though full of a pietism and a paternalism which were to adversely influence later events, is not the kind we now need. On the contrary, it tends to hold back change and buttresses the status quo.

While the case is not simple, that is, there is the recognition of sincere efforts on the part of some of the North Americans in the past to collaborate with the nationals, nevertheless the unequal distribution of power which was, for complex reasons, tolerated in the past, is no longer tenable.

Ahumada goes on to describe how the Protestant Church is viewed by many as a propaganda cultural arm of the U.S. that seeks to highlight the advantages of the "the American way of life." Whether or not that is the aim, he writes that it is with good reason that people feel this way because that is an effect of the uneven distribution of power that finds its base in racial and cultural relations. He recognizes that even the 
preaching of "the" gospel, often imagined to be a pure inspiration of the Holy Spirit, is not immune from the influence of the colonial system: "Well-informed theological and biblical sources indicate that the gospel known in Latin America is really a capitalistic interpretation of the gospel and missions have been a vehicle for a foreign culture which has been mixed with the preaching of said interpretation of the gospel."

Recognizing the need to decolonize the imagination, Ahumada goes on to argue that the result of this lack of equity is that it "has produced in many persons an exaggerated and false sense of loyalty, of gratitude, and, in some cases, of servility. Through this typical heritage of conquered and colonized peoples the missionary is converted into a person of admiration, devotion, respect and obligation." His letter grows with a swell as he begins to describe the actual effects of the material conditions of the missionaries on relations of spirituality and "fraternity." Speaking of the missionary, he explains, "[a]s an individual he is deified because of what he represents: the word of God. He is superior to any national; he has everything, including the power of control and money." He now begins to untangle the colonial dynamics that have animated relations between the institutions:

And here is an important point of difference. The missionary has always, with very fuew [sic.] exceptions, maintained himself on a level above the national, not only by his influence and contacts which come from the simple fact of his being a foreigner, but by his fortunate economic situations. While the national pastors have starvation salaries, and generally have had to dedicate a good part of their time to secular work in order to survive, the missionary has an income at least superior to that of the average Colombian professional. From this fact comes the first and most important inequality between the two types of workers and this inequality is often sufficient to cause the Protestant community to place the missionary on a pedestal as a model of all the good within reach. 
As though the inequality of these relations were not enough, Ahumada clarifies that the significant reason that this is a problem is because the Colombian Protestant community, when inundated by such conditions, no longer has the faith or trust in Colombian nationals to address their own problems, and that's assuming that the particular ideologies of the North American interpretation of the gospel don't deaden their sense that there is a problem in the first place. Rather, Ahumada argues that it is specifically at this world historical moment, right after the second Vatican council and with Latin American Liberation Theology sweeping the region, that now is the time when Colombians must believe in themselves more than ever, must take stock of and engage with the problems that threaten their community; this is the moment that he sees the activities of the PC(USA) workers as anathema to Colombian well-being. As it is at the time, however, rather than being animated to struggle for justice, those converted to the faith become further abstracted from the conditions of their life.

Now he finds himself in a society resigned to give the maximum time possible to the Church, to evangelism, to the conquest of others for Christ, in order to liberate them; in a society where a concern for the real problems of the people is something apart from Christian conviction and only serves to draw a person away from the Lord.

He goes on to tell of pastors being excommunicated because they desire to engage the gospel with the conditions of life, ("begins to speak to his congregation in terms of reality") for which the North American message has left no space. He tells of other pastors who believe their community to be abandoned because they do not have a missionary working with them: "missionaries are requested urgently. Nationals in places without fraternal workers even become envious of those places with a good number of them." Ahumada concludes by reducing "the true situation" in Latin America to this fact: 
"the existence of an oppressed people and of an oppressor people." His final crescendo

offers no concrete prescriptions for moving forward, only recognitions.

Where does the Presbyterian Church of the United States fit in this Latin American situation? The United States is one of the causes of oppression in Latin America and it concerns me greatly that the ecclesiastical agencies form a part of the foreign policy of their government. It makes me concerned when I think that the donations which our Church receives from congregations and persons in the United States are given with the interest of maintaining at all cost the status quo, through palliative social work and the preaching of the gospel which we already know, or that they are simply a good investment for maintaining peace. I am concerned when I see the ecclesiastical agencies strain themselves to help the national Church through the sending of missionaries and not through simply providing funds as it could do in many cases. Is it possible that they wish to maintain control of the faithful forever through the fraternal workers? Why the eagerness of most of the fraternal workers which have no other effect than that of helping to deaden oppressed consciences?

The conclusion admits there is no proposal, but rather requests an earnest reflection by the officials at COEMAR.

The COEMAR should also rethink its position in relation to these charges, and the necessity of or utility of the present type of missionary, or a total transformation toward a new and dynamic fraternal worker who will be on the side of the oppressed people and help them come out of their lamentable state, identifying himself with their ordinary life, sharing their aspirations and sufferings, on their level, not over them; leaving the control of the situation once and for all in the hands of the nationals. Or, if this position is not possible, the COEMAR should decide about the appropriateness of helping its sister Church in a form other than by the sending of more fraternal workers, helping it to find itself and the type of gospel which it should preach and demonstrate in a society which is changing at a furious pace.

The IPC, like any community, was never itself a homogenous institution. While reviewing unpublished histories this summer I came across numerous historical letters representing a host of different political positions. Although some more radical letters to the PC(USA) called for an expulsion of fraternal workers due to an inability to sufficiently decolonialize relations, others rebuffed their North American counterparts for 
funding a group of radical, known Marxists, identified as the "Rosca de Investigación"; this was, in fact, a group of social scientists, notably formed in large part by Orlando Fals Borda, one of the great sociologists and defenders of the Colombian people, to be considered more closely at this point.

By $1970,72 \%$ of Colombian families made less than $\$ 600$ a year and it was estimated that $80 \%$ of the economy was controlled by $2 \%$ of the population (Fals Borda 1971, p. 43). This was the time that the Rosca gained an important role in Colombia. The Rosca was comprised of a small group of sociologists that wanted to work to serve the vulnerable communities in Colombia. The original group included Gonzalo Cárdenas, the IPC minister already mentioned; IPC minister and economist Augusto Libreros; Dr. Victor Daniel Bonilla, a Catholic philosopher; and the social scientists, and later M-19 member, Carlos Duplat. And perhaps the most prominent member of the founding group was Dr. Orlando Fals Borda, who played a significant role in the group's formation, and the type of social science that later issued from their practices.

Fals Borda had grown up in Barranquilla, Colombia, and graduated from the Colegio Americano; the IPC would be his home church until he came into conflict with the conservative elements of the community. Fals Borda had graduated from the University of Dubuque with a degree in English Literature and History in 1947.

Afterwards, he moved to the United States to pursue further education. At the University of Minnesota he conducted his Master's under the sociologists Lowry Nelson, whose work focused on rural communities, and Pitirim A. Sorokin, who had first initiated studies in rural sociology. Under their guidance he wrote a thesis entitled "Campesinos de los Andes" (Farmers of the Andes). At the University of Florida, Fals Borda pursued his 
$\mathrm{PhD}$ in Latin American Sociology under the guidance of Thomas Lynn Smith, a former student of Sorokin's, who authored the then influential Sociology of Rural Life. His doctoral dissertation was entitled "El Hombre y la Tierra en Boyacá" (The Man and the Land en Boyacá) He would later publish both his thesis, in 1955 and '57, respectively (Ocampo Lopez, 2009, p. 17).

Upon finishing his $\mathrm{PhD}$, Fals Borda returned to Colombia, eager to apply and expand upon the discipline he had learned within his home country. In collaboration with his close friend, Father Camilo Torres Restrepo, he organized one of the first sociology faculties in Latin America at the National University of Colombia, and served as the Dean from 1959-1967. His goal and hope was to establish a generation of sociologists capable of conducting scientific research about the social reality of Colombian life. Father Camilo, as a professor, critically analyzed the social reality in Colombia and became a part of the Christian Revolutionary Nationalism that was emerging from more general movements of progressive Catholic followers around the continent after the Second Vatican Council. His death had a profound impact upon Fals Borda (Ocampo Lopez, 1972, p. 22-38). Later he founded Colombia's first graduate program in Sociology with the help of Germán Rama, Jorge Graciarena and Guillermo Briones, amongst others (Ocampo Lopez, 2009, p. 15). In collaboration with Gabrial García Márquez and Enrique Santos Calderón, Fals Borda founded Alternativa, a radical journal in the 1970's.

His long-time friend and colleague Gonzalo Castillo-Cárdenas (2010) describes the different stages in the life and work of Fals Borda. He refers to the first period of his professional career as a stage of empiricism and objectivity, which resulted from his work with the U.S. sociologists. The emphasis among U.S. sociologists of the time was 
paradoxically that of objectivity, value-neutrality, while simultaneously being fixated on particular ideologies of progress and development. Castillo-Cárdenas affirms that in Orlando's work on Boyacá, one can sense that the problem with these rural farmers was that they were "behind" (2010, p. 16).

He describes the next period, "compromiso," an important concept in Catholic theology and the European left, as having been heavily influenced by Fals Borda's relationship with Camilo Torres. It was Camilo that had insisted that sociology ought to be "comprometida con la transformación social," and this was the bond that brought Fals Borda and Torres together. However, it wasn't only the relationship with Torres that helped to develop the importance of commitment as an ethical imperative for Orlando, but also his engagement with the World Council of Churches. He attended the First World Council of Church and Society in Geneva in 1966. Castillo-Cárdenas believes that this council was the first truly ecumenical conference in the history of Christianity because it was the first to bring in groups from not only the so-called first world, but all worlds as well. The conference was oriented around the theme of praxis. One of the speakers at the conference was Richard Shaull, who Orlando had already known and admired from his time at the Presbyterian Youth Center in Barranquilla during the 40's (Benavides y Castillo-Cárdenas 2010, p. 17). Shaull at that time was at the forefront of organizing radical new youth movements in Brazil, and spoke at the Conference, somewhat dangerously, of "the theology of revolution." On the relationship between what would later be called Liberation Theology and Shaull's Revolution Theology, Castillo-Cárdenas writes that, 
[a]unque no hay evidencia de que esta intrigante excursión teológica, anterior a la Teología de la liberación hubiera hecho conexión con la visión espiritual y ética que Orlando había recibido de sus padres y de la Iglesia hasta ese momento, lo que sí queda claro es que tanto Camilo Torres como la Conferencia de Ginebra imprimieron aún más en Orlando la necesidad del "compromiso" como componente imprescindible de la práctica social. (Benavides y Castillo-Cárdenas 2010 p. 17)

It was in this context that Fals Borda developed the notion that for Sociology to be relevant it must embrace and engage a commitment to transform the world with those struggling under exploitation and injustice. This was the foreground for the development of a third period of his life, Participant Action Research (PAR, or IAP in Spanish).

By the time la Rosca began working it had as a goal (what would later become PAR/IPA) to avoid creating a state of dependence with respect to an intellectual elite by conducting the research as a part of the community to which it was dedicated and returning the results to the community for criticism, action, cultural identity and social cohesion (Fals Borda 1986). Their methodology was one truly concerned with popular empowerment, and every study they undertook or datum collected were shared and propagated among the community in order to increase their resources to respond to their conditions. This emphasis corresponded with the move of Liberation Theology to empower "historical" subjects, to show individuals that they were workers and creators of their own history. The books published contained not only collection of scientific data but also displayed these "knowledges" alongside popular tales and folklore as told by the inhabitants of the region. Their project was one that sought to decolonialize knowledge and show the Colombian people that they themselves had the power to affect the conditions of their lives. The impact of the Rosca upon the national consciousness and beyond has been profound. 
The Rosca was a vehicle focused on the people. It rejected the free-market while also condemning the dogmatic Colombian communist reaction. The Rosca declared a relentless autonomy despite funding from the PC(USA) and the World Council of Churches (WCC). Nevertheless, at the beginning of 1972, the Southern Presbytery in Colombia released a declaration condemning the PC(USA) for interfering in the internal politics of Colombia because their Committee on Self-Development of People supported the Rosca with an annually reviewed $\$ 75,000$. The letter claimed that the Rosca was a Marxist group. It was translated into English by a non-Colombian and widely distributed in the U.S. and Colombia. A Cuban who had left his country after the revolution saw the declaration and published his own article in the Presbyterian Layman, entitled "Why Should We Promote Marxism?” (Rodríguez 1992, p. 92). A report by the PC(USA) showed that it was a missionary who had long been working in the south who urged the publication of this initial document, which Rodríguez (1992) quotes in a footnote:

"Report of the International Task Force on the Synod of Colombia and the Rosca de investigaciones". 17-4-72. "...the present Stated Clerk of the Synod and Moderator of the Presbytery of the South, that Presbytery, and subsequently the entire Synod adopted the resolution at the urging and under the guidance and personal direction of the UPCUSA missionary. This particular missionary wields considerable influence in Colombia by virtue of longevity, tenure and acces [sic.] to funds in the United States". (p. 92)

This altercation ultimately ended up helping the relationship between the IPC and their colleagues to the north as it further focused attention on the need to clarify their mission and to select missionaries who would be inclined to support IPC autonomy.

Nevertheless, and a painful example of the ambivalent positions Christian communities endeavored to articulate in response to the politico-economic crisis during this period, the position of the Southern Presbytery prevailed. The reason was that the 
issue of autonomy was ambiguous in this situation. Even though it was a domineering missionary who had personally championed the condemnation of the Rosca, if the PC(USA) rejected the declaration of the IPC's Southern Presbytery, it could be portrayed as imperialistic interference. Rodríguez (1992) reproduces the consequence decisions: “en las actas de la XXVII reunion del Sínodo, Medellín, 10 y 11 de Enero de 1974. 74 C 006 SBI \# 3 y 4:"

3. Que la Iglesia Presbiteriana de Colombia, en uso de su natural derecho, entable relaciones con otras Iglesias de la familia Reformada, siempre que tales relaciones no pugnen con la orientación teológica de la Iglesia Presbiteriana de Colombia; 4. Que se reconozca el Sínodo la suprema autoridad en todo lo relacionado con la Iglesia Presbiteriana de Colombia; y por tal razón, que ninguna Iglesia Presbiteriana hermana inicie proyecto alguno, directa o indirectamente, dentro del país, sin la previa consulta con y la aprobación del Sínodo. (p. 93)

There were other positive outcomes of this complex event. During this meeting, older properties which had been still originally titled by U.S. entities from the original missionaries were signed over to the IPC, and an agreement on finances was made that the IPC would provide $50 \%$ of its budget and that the other $50 \%$ would come "con ayuda foránea de buena voluntad" (p. 93).

The IPC more recently repented publically of the condemnation issued to Fals Borda and the group, whereupon there was reconciliation with the Church, which he called home. The story of the Rosca, among others, demonstrates that the IPC has been a fragmented space, which eventually suffered its own official split in the 80 s over the very question of how to authentically engage faith within a modern oppressive system that has emerged out of colonial conditions. In fact, a more precise description would be that a great many people, motivated by the hopes for worlds and knowledges otherwise, had already articulated that response. Popular education programs were started, a system of 
schools proliferated, and a large part of the reason for the split was due to the formation of a theological seminary intended to create the possibility for community and scholarship which related to local problems and knowledges outside of hegemonic discourses.

The 80 s brought much change to the IPC, in particular through 3 events: the creation of Presbyterian Theological Seminary, a split that occurred in the Central Presbytery, which profoundly affected the entire IPC, and the tragedy of Armero. On November $13^{\text {th }}, 1985$, the city of Armero disappeared under avalanches called by the eruption of the Nevado del Ruiz volcano. While 20,000 people perished in the tragedy, the IPC lost some of its most recognized leaders that day. The IPC institutions in Armero were among the country's strongest, and the Colegio perished under the destructive forces of mudslides. The IPC, PC(USA) and other religious organization banded together to rebuild Armero in the zone of Lérida, and to get aid to the nearly 9,000 survivors.

With regard to the formation of the Seminary, it is by now clear that the emphasis on the importance of education has remained a defining aspect of Presbyterian activity in Colombia, as seen by the intense development of the Colegios Americanos. The idea behind the Colegios is that they are key to positively influencing the society. Pablo Moreno points the three objectives of the Presbyterian education offered in the initial years of its implementation:

Primero, crearon escuelas como forma de sacar del ostracismo social a individuos pobres habitantes urbanos, y algunos sectores rurales con proyección a lo urbano, con el fin de capacitarlos para ser útiles en la sociedad; existe aquí identidad con el ideal de los liberales radicales para quienes el objeto de la educación era el hombre común y corriente al cual hay que preparar con los elementos mínimos que le permitan integrarse a la sociedad del porvenir, la industrializada. Segundo, usaron los colegios y escuelas para tener contacto con la comunidad local y así 
establecer las bases para una futura congregación. El Alfabetismo era una necesidad de la sociedad en general, suplirla daba la oportunidad de articularse con una comunidad y así realizar un proselitismo promisorio. Tercero, quizá el objetivo más importante para obtener influencia en la sociedad, fue el de educar a los hijos de la clase media ascendente que tendrían oportunidad de llegar al poder en un futuro y desde allí favorecer el establecimiento de los protestantes bajo la bandera de la libertad religiosa. (p. 70)

The student population of the Colegios had reached 15,000 by 1986 , with large schools in Bogotá, Barranquilla, Bucaramanga, Ibagué, Girardot and, until the tragedy, Armero. Today the Colegios serve the middle class during the day, with evening class offered for those that can't afford to attend during the day.

As already mentioned above, it had long been agreed that there was a need for a theological formation among the IPC community. In the past, under the direction of the Reverent Clifford A. Douglas, they began a program based out of the Colegio Americano. This program continued with success for roughly 30 years. Back in 1944 , Alfonso Lloreda and Luis Quiroga, graduates from the Colegio and members of the IPC, had entered the Princeton Theological Seminary. In April of that same year, activities for the Evangelical Faculty of Theology began under the auspices of the Presbyterian Mission and under the direction of Richard Shaull (Rodríguez 1992, p. 53). The idea for these programs had been to work toward the establishment of developed Theology Program to train and introduce local ministers to emerging hermeneutical approaches to the Bible that would be politically and socially relevant to the Colombian context. However these programs floundered off and on for years, until eventually they decided that it would be best to send qualified students to study outside of the country in the Seminary in Matanzas, Cuba. Those that have studied in that program include Gilberto Torres, an IPC pastor in Bogotá, Eugenio Illidge, another IPC pastor in Bogotá, and 
Gonzalo Castillo, an IPC pastor and founding member of the "Rosca de Investigación"

(Ordoñez 1956, p. 127-8). John Sinclair describes the attempt to form a Theological

center for Protestants in Colombia:

Se comenzó un pequeño curso ministerial en Barranquilla en 1916. ... más tarde se formó en Bogotá un 'seminario' presbiteriano pero de nivel inferior. ... Unos estudiantes fueron al seminario Bíblico en Costa Rica, establecido en 1923. Otros estudiaron en el seminario unido de Puerto Rico entre 1946 y 1962 y varios presbiterianos estudiaron en el seminario evangélico de Matanzas, Cuba. Pero nunca hubo ningún centro de alto nivel de estudios teológicos protestantes en Colombia. (Sinclair 1981, p. 590)

Yet it was in 1982 that the community was finally able to organize effectively the creation of the Reformed Theological Seminary. Some of the main focuses in the design of the Seminary were to "atender en su formación a las necesidades de la población urbana y rural, la libertad de cátedra teológica, la expresión pluralista, y la búsqueda de una profesionalización excelente, etc.” (Rodríguez 1992, p. 96).

The stated emphasis of the seminary is not only the study of the Bible but contextualizing it with the Latin American experience:

[L]os alumnos del seminario aprenden los idiomas originales y las técnicas básicas de exegesis e interpretación bíblica. Cada estudiante ha de ser capaz de determinar el mensaje de la Biblia por sí mismo sin depender de la interpretación de otros.

Por eso también el seminario hace hincapié en la lectura de la Biblia desde América Latina. Por mucho tiempo los más notables avances en la teología provenían de Europa y Norteamérica. El seminario reconoce y hace uso de esta rica herencia teológica, pero busca contextualizar el mensaje del evangelio en la realidad de América Latina, ayudando así a la iglesia evangélica y reformada en la búsqueda de una mejor comprensión de lo que significa para nosotros ser el pueblo de Dios en Colombia, Venezuela o Ecuador en este momento histórico. (Seminario Teológico Presbiteriano. Informe al Venerable Sínodo. Ibagué, 20-25 de Enero de 1988; quoted in Rodríguez 1992, p. 97) 
Although a majority of the students enrolled come from a Presbyterian community, 1/3 of the students do not, which represents the IPC's commitment to collaboration, community and dialog.

According to Maria Arroyo, the Latin American Area Coordinator for the PC(USA), it is surprising that the IPC lasted as long as it did without official schism, as most of the Churches in Latin America had undergone splits throughout the 60s to early 80s on account of the difficulty of forming a Christian response to the politico-economic conflicts of the era (personal interview). Conflict had been brewing in the IPC, besides stemming from other issues, increasingly over the alliances formed with other groups, which was strange considering the IPC's history.

Since other Protestant denominations began arriving in Colombia in the 30s, the IPC has been collaborating with other groups. The IPC was a chief proponent and founding member of the organization Confederación Envangélica de Colombia (CEDEC), which works for the unity and cooperation of the Protestant communities in Colombia to this day. In 1957, the following was written into the statutes of the IPC:

El Sínodo contempla como una Meta sagrada la formación, tan pronto como sea factible, de una sola Iglesia Evangélica de Colombia, en la que estarán asociados todos los Evangélicos del País. Para la realización de tal ideal la Iglesia Presbiteriana de Colombia, representada por el Sínodo, se declara dispuesta a entrar en estudios y conversaciones con cualesquiera otras Iglesias Evangélicas en la República, acerca de las bases sobre las cuales se pudiera establecer tal Iglesia Unida. (Estatutos Sinodo, 1957; quoted in Rodríguez 1992, p. 49)

The IPC has always shown interest in collaboration, despite those less disposed toward such integration.

Leaders of the Central Presbytery didn't want to be involved with outside groups, suspicious of their motives, and increasingly concerned to stay neutral in the national 
conflict as the 80 s were an intense time of escalation in violence. When the IPC became involved with CONELA (Confraternidad Evangélica Latina), as a minister from the Central Presbytery attended and participated in its formation, some members of the community were upset. In a Synod meeting it was decided to not affiliate in any of the two largest organizations of Churches in Latin America. "A partir de ese momento se empieza a deformar nuestro sistema y orientación teológica originando serios conflictos a nivel sinódico ante las alternativas CONELA o CLAI [Consejo Latinoamericano de Iglesias]" (Rodríguez 1992, p. 100).

The conflict continued to escalate and by 1988 , a portion of the Central Presbytery wrote a letter declaring their independence from the IPC. They were weary of the direction of the Church, and uninterested in the socio-political aims of Liberation Theology. As one member told me, "We already watched the news with all that violence and conflict. That's not why we come to Church. We can stay at home and watch TV if we want that." It seems that for a segment of the community, they were more interested in Church being a place of rest from the pervasive and incessant terror that has persecuted the country indefinitely, rather than a tool to confront it. Through a slim margin, the progressive leaders of the Central Presbytery were able to keep the Colegio Americano, and a few of the Churches, although the most well-known Churches in Bogotá were maintained by the group that seceded. This period of secession is still a very sensitive topic and readily felt by those that were involved. The most pervasive commentary on those events now is that the split had as much to do with personality as it did ideology. The new, small, and isolated faction is known as the PC (Presbiterio Central), but they obviously have no interest in working with the PC(USA), or other groups, opting for 
seclusion and a more 'spiritual focus.' After the split, the IPC submitted an analysis of the schism to the Assembly of AIPRAL (Asociación de Iglesias Presbiterianas de América Latina) in August of 1991 in order to assess any positives, maturity, and enrichment that the conflict had produced:

nos referimos al hecho que se puso al descubierto los profundos vacíos, desaciertos y malformaciones en los aspectos: administrativos, constitucional, confesional y pastoral. Por lo tanto, se hizo necesario implementar los correctivos que puedan darle a la IPC nuevas dimensiones. (Rodríguez 1992, p. 108)

There are a lot of complex feelings today about the causes and consequences of this split. Despite the recurrent commentary that personality played as big a role as material or ideological conditions, some have suggested that the differences between the two factions were regional, and could be accounted for by the certain and occasional regional sparring known to take place between those from the interior of the country with those from the coast. Still, some other members do reference the importance of the ideological differences, and from both sides. As the member quoted above argued, some members of the community see the church as a place for refuge from the emotionally and spiritually draining omnipresence of the national conflict, a place to praise God and feel comforted, while others see the church as a resource for confronting and challenging the conditions that have led to the prolonged violence and displacement in the country.

For the IPC, the consequences of the split to the direction and leadership of the community have been clear. Having retained the Colegios and a significant number of the Church property after the schism, and with much of the conservative leadership having opted to leave, the path was clear for the progressive leaders to design a more direct path of confrontation and political engagement within the national conflict. According to the 
current Executive Secretary of the IPC, Jairo Barriga, although the conservative elements of the IPC had previously struggled so vehemently against international affiliations and collaborations, their departure opened up new space to develop stronger relations with interested international parties, which has made a significant impact on the Church's direction over the last 20 years. It was in 1994, as they were seeking to heal and find new direction after the schism, that the Church began to realize the importance of what they call Ecumenicism. While this idea expresses the hope for a greater Christian unity and cooperation amongst distinct groups, because the IPC values interfaith dialog and actively seeks to collaborate with any group interested in responsibly struggling for a more just society, ecumenicism in this context fully coalesces with those secular analyses that have called the other end of top-down economic expansion a "globalization from below." And yet there may be components of what's enabled and involved in a longstanding religious network's "globalization from below," such as what's seen in the case of the IPC, that haven't received sufficient attention or appreciation. Barriga recognizes that the IPC's willingness to work with Catholics, Pentecostals, Muslims, or secular civil society groups has caused many within the Protestant communities of Colombia to question the IPC's commitment to faith, but he feels that they have seen in the last 10 years a radical opening up of effectiveness and opportunity through such alliances and collaborations.

\section{THE IPC NOW: GEOPOLITICS, ALLIANCE AND RESISTANCE}

When I returned to Barranquilla in the summer of 2012 to conduct field research, the most striking aspect about the IPC community was its sensitivity to their history. And 
perhaps sensitivity isn't the right word, as though wounds were always still too fresh (although sometimes that, too). Cognizance would be a better way to talk about it. In nearly all of the conversations I had and observations I made, what stood out was a sober circumspectness about how their history should inform present strategies. As others have suggested, the relationship between memory and ethics suggests that the commitment to remembering is a political act (Fanta 2009). The emphasis on education within the community implies a conscious remembering which never escapes the planning of present and future initiatives aimed at social transformation. While my research took me to Barranquilla, Santa Marta, Cartagena, Bogotá, and Medellín, at some point it began to strike me that the communities were only located within particular regions, but that there seemed to be an invisible line, south of which the Presbyterian Church had no presence. Finally, I asked one of the pastors: "Is the IPC not throughout the whole country?" She responded:

It's not. In good colonial fashion, earlier on, kind of like countries divided up Africa...[i.e.] 'you can have this, and you can have this,' and all that stuff, Churches did that as well, and in Colombia the south [south of Bogotá] was U.S. Cumberland Presbytery, and like once you get below Bogotá, like Cali has Presbyterians, they are Colombian Presbyterians, but the IPC doesn't really go past Bogotá.

Cumberland Presbytery was a smaller faction of the U.S. Presbyterians that had split off from the PC(USA) while still in the United States in the early 19th century. However, apparently, as they endeavored to negotiate how they would each fulfill the great commission, (and whether that refers to Christ's command to evangelize the world or to Manifest Destiny and the White Man's burden, and whether these were interpreted as mutually exclusive goals altogether, is anybody's best guess) their leaders withdrew a 
map and marked a line horizontally through Bogotá, the capital, and across the country, effectively 'giving' the North to the PC(USA) to evangelize and the South to Cumberland Presbytery. ${ }^{24}$ If the question of maps and who writes space could ever seem innocuous, it is anything but that; rather, it always implies the authority, legitimate or otherwise, to represent and declare space.

Toal (1996) describes the emergence of map-making during the colonial period as co-incident with other forms of power-knowledge technologies that came to predominate. Described as geo-power, he contextualizes the dividing of territories onto maps as "the functioning of geographical knowledge not as an innocent body of knowledge and learning but as an ensemble of technologies of power concerned with the governmental production and management of territorial space" (7). This is all the more telling within the context of a religious imaginary in which cosmic ideology commingled with and was animated by teleological notions of race and power (Dittmer 2007). This story, besides highlighting the historically present legacy of colonialism and evangelism, demonstrated the sensitivity based in historical understanding to autonomy and equality with which current leaders, from both the IPC and PC(USA), plot and negotiate solidarity. This commitment to allow a history of power-imbalance to animate contemporary strategies of linking and alliance is one aspect of the Presbyterian network in Colombia which enables members from different nations to strive for respect and equality in a way that NGOs,

\footnotetext{
${ }^{24}$ There appear to be no documented record of any such activity, only that this story is repeated among members of the community. Other interviews revealed that this Cumberland Presbytery is an exceedingly small sect, with little presence in the south of the country. The Cumberland Presbytery does meet with the IPC leaders once a year to discuss trajectory and occasional collaboration, but these instances are informal and the Cumberland group seems to be largely isolated from other institutional affiliations.
} 
civil society institutions, and other actors involved in transnational alliance may not be able to appreciate, or at least replicate.

\section{GEOPOLITICS AND TRANSNATIONAL STRATEGIES}

There are no relations of power without resistances ... like power, resistance is multiple and can be integrated in global strategies. ${ }^{25}$

The transnational strategies of the IPC to be considered can be appropriately oriented in terms of geopolitics and geopolitical resistance. Geopolitics is a term that was developed around the turn of the 20th century by Swedish political scientist Rodolph Kjellén and German geographer Freidrich Ratzel (Toal 1996). The concept has a storied history that encompasses political actors ranging from former U.S. Secretary of State Henry Kissinger to the former military dictator of Chile, Augusto Pinochet, who in 1968 wrote his guiding political treatise, Geopolitica. In general, geopolitics is associated with philosophies of the state as espoused by its elites, and conjures the game of Risk where questions of resources and territories are central, and factors such as populations are contingencies to be controlled. The ways that the Liberal and Conservative parties leveraged the growth and engagement of the Protestant and Catholic initiatives respectively recalls this model of hegemonic geopolitics that critical responses have sought to challenge

With the rise of post-structural thought, the field of critical geopolitics has since emerged. While this field can be thought of as a critical response over and against dominant "top-down" geopolitics, it has largely been a textual intervention focusing on modes of discourse and representation. Who decides what contours are to be mapped,

${ }^{25}$ Foucalt 1980, p. 142. Quoted in Routledge 2003. 
according to what logic, and for whose benefit? When geographer Geróid Toal describes critical geopolitics, he writes that its "mode of operations is a mobile, guerilla one that uses what is at hand within a terrain governed by hegemonic political understandings in order to advance critical positions in a permanent war of position" (1996; 69). Routledge has further articulated the idea of anti-geopolitics, which seeks to focus on people's movements of resistance to dominant geopolitics. "These histories of resistance can be characterized as a 'geopolitics from below' emanating from subaltern (i.e. dominated) positions within society that challenge the military, political, economic and cultural hegemony of the state and its elites" $(2003 ; 236)$.

Most recently Sara Koopman has contributed the innovative concept of altergeopolitics. Drawing on her dissertation research which focuses on accompaniment and the pacifist community of San José de Apartadó in Colombia, Koopman uses the work of feminist geopolitics in order to re-scale resistance at the level of the body and analyze how individuals strategically link in order to share security. She writes, "I am interested in how geopolitics is thought differently not just by writing about bodies, but by moving bodies. I am interested in the thinking that is being done in and through action, particularly by those that are using their bodies, together, to build alternative nonviolent securities" (Koopman 2011; 277). Whereas anti-geopolitics describes how groups push back against hegemonic politics, alter-geopolitics indicates the ways that groups nurture "other types of nonviolent security in connection [with] what they do want... Grassroots groups are not waiting for (or trusting) the state, but coming together on their own, nonviolently, for safety" (Koopman 2011; 277). Accompaniment has become a significant 
method for achieving a level of security, which is why the IPC has implemented their protective accompaniment program.

\section{PROTECTIVE ACCOMPANIMENT}

Protective accompaniment, also known as Third Party Non-violent Intervention (TPNI), involves placing privileged bodies, ones that are either less threatened or less likely to be threatened, alongside bodies that are at risk or under threat. The classic text on this practice was written by Mahony and Eguren, themselves experienced accompaniers, which they define as "unarmed bodyguards" (1997). This model was first developed by Peace Brigades International (PBI) in Central America during the early 80's. TPNI began with trained volunteers and was deployed for the first time in 1983 when a group of ten volunteers were sent to Jalapa, Nicaragua, a community alongside the border with Honduras that was being threatened by the U.S.- backed Contras (Eastwood 2009). They soon expanded to Guatemala and other vulnerable communities, finding their work as "unarmed bodyguards" was proving to be successful. Soon PBI's mission in Jalapa was taken over by Witness for Peace (WfP). Linda Eastwood, who helps to train the accompaniers sent to the IPC now, tells that WfP was established in 1983 "as a direct result of a study tour that took thirty North Carolinians to the smoldering remains of the village of El Porvenir, where, with Contras across the Honduran border in full sight, the villagers told the visitors that the only reason they were not still being attacked was that the foreigners were there" (2009). Today, international accompaniers work in over 10 countries, with Colombia being home to the largest number of groups, including: Christian Peacemaker Teams (U.S./Canada), Fellowship of Reconciliation (U.S.), Swedish Fellowship of Reconciliation, Project Accompagment 
Solidarité Colombie (Quebec, Canada), The European Solidarity Network, Espacio

Bristol (UK), Peace Brigades (Europe/U.S.), International Peace Observatory

(Europe/U.S.), Witness for Peace (U.S.), Palomas de Paz (Italy), and, the group that collaborates with the IPC, the Presbyterian Peace Fellowship (U.S.) (Koopman 2011, p. 278).

Accompaniment is inherently a complex and potentially problematic strategy. In that it relies on the privileges afforded to particular bodies over others, it has the potential to reify, rather than subvert, those colonial categories of privilege. This dynamic is not lost on the volunteers:

My most animated discussions with accompaniers have been about the paradox inherent in their work. They are using the fact that their lives 'count' more (because of passport/economic/racial privilege, which are hard to untangle), to build a world where everyone's lives 'count' - where it matters when a chocolate farmer is killed in the Colombian jungle. When you use privilege in this way do you make it stronger? By looking closely with accompaniers at how they 'make space for peace' - how space is something that they practice, produce and perform every day - we got a sense of the many ways privilege is at work. ... Yet it is precisely the process of struggling with such contradictions, and the thinking through of what works on the ground and how and why, that are worth both learning from and contributing to. (Koopman 2011, p. 280)

Eastwood has likewise noted the challenges of using privileged bodies as a strategy for combatting violence and creating secure space. For example, there is a tendency for accompaniers to be white as a result of

the desire of the accompanied to have someone alongside them who they feel most obviously represents the 'power behind the power' (often the U.S.) that they need to confront... Racial imbalance is assuredly present in the Presbyterian Accompaniment Program; most of the accompaniers are Caucasian. This does not stem from the desires of the Colombian partners; indeed they were quoted as asking pretty stridently when we are going to send African-American accompaniers, given that so many of the displaced people with whom they work are Afro-Colombian. (2009) 
She goes on to note, in addition, that there has been hesitancy on the part of non-white U.S. accompaniers due to concern about whether or not they would be safe without the "white skin protection" that more clearly marks a U.S. citizen in Colombia. Although accompaniment is strategically taking advantage of these dynamics in order to create spaces for peace, abiding colonial relations must also be combated. This recalls the way that the Madres de la Plaza de Mayo took advantage of their roles as mothers and women to brazenly call for justice and confront the state, while simultaneously struggling against the cultural machismo which enabled their advocacy through stereotypes about the special rights of mothers.

\section{THE EMERGENCE OF ACCOMPANIMENT IN THE IPC ${ }^{26}$}

Despite ambiguous histories and, at times, split political identities, the IPC increasingly began to request the solidarity of the PC(USA) in recent years. As "Plan Colombia," the prominent billion dollar militarization program designed by the U.S. and corporate interests, was at the cusp of being introduced in 2000, the IPC, the Commission of Human Rights and Peace of the Council of Churches of Colombia, were writing to the PC(USA) requesting solidarity in denouncing U.S. military aid. In 2003, after then President Uribe had commented that human rights workers were "politicians in the service of terrorism," the IPC again wrote to the PC(USA) requesting letters to Uribe. As the IPC had overtly become involved in human rights advocacy, and in a country where a union leader has been assassinated on average every 3 days for the last 20 years, such an

\footnotetext{
${ }^{26}$ The vast majority of this story comes from interviews with Diego Higuita, Milton Mejia, German Zarate, and 2 unpublished documents written, and graciously shared with me, by Linda Eastwood, who currently facilitates the Protective Accompaniment from the U.S. end. German Zarate facilitates the program on the part of the IPC.
} 
accusation from the president is not idle political posturing but carries material consequences.

On the coast, where the IPC has its largest presence and influence, Church members had begun working on behalf of the increasing flow of displaced people - those displaced primarily by guerrilla and paramilitary violence - into Barranquilla and the surrounding areas, many of whom turned to Churches for help. In Urabá both the city in general and the IPC communities in particular have been some of the hardest hit in the region by the violence and subsequent displacement. ${ }^{27}$ It was clear not only that the Church lacked the resources needed to meet all the physical needs of the displaced but also that they needed to do more to address fundamental issues of the conflict, both recording the abuses from which people were fleeing, and helping them to establish their lives in the city through civic and educational initiatives. The Church decided to join its efforts and resources with a group of local law students in order to found CEDERHNOS (Corporación Centro de Estudios y Desarrollo de los Derechos Humanos). The goal of the center was to provide public assistance that would help educate people about basic issues related to living in a city and their legal rights, including the government benefits to which they were entitled with the process of petitioning for land.

As the Church became more involved in human rights, the community increasingly found themselves being threatened. In addition to the harassment, they began to be accused of being guerrilla sympathizers in response to their work with the displaced, a very serious accusation in a context of an escalating militarization of the

\footnotetext{
${ }^{27}$ One community member told me that Urabá is a city with the infrastructure for maybe 30,000 people but that number has jumped to over 300,000 and still rising over the last 10 years with the increase in displacement as a method of warfare.
} 
conflict. Reverend Milton Mejia, then the head of the IPC, was regularly receiving menacing telephone calls. "In November 2002, a Colombian paramilitary leader was arrested for making calls threatening Mejia's life, but in early 2003 he 'escaped,' released on a prison day-pass from which he never returned. (The sense that "the authorities" might not always be helpful was amplified when, during the interrogation of the young lawyer arrested in 2004, the IPC learned - from tapes that he was shown - that the Church offices had been under video surveillance)" (Eastwood 2009). IPC moderator Diego Higuita and Mejia both began writing to partner Churches in the United States, asking them to be aware that the Church might need help protecting Mejia and his family should "an emergency situation" arise. Personal threats and attempts at extortion to Mejia and others increased, and the IPC wrote to the PC(USA) requesting accompaniment. "Both the risk and the need were very real; the Council of Evangelical Churches of Colombia reported that in 2004, armed groups murdered forty Protestant leaders, and more than fifty congregations were closed due to violence" (Eastwood 2009). Utilizing Presbyterian networks and alliances, Mejia and his family were able to use an invitation by the PC(USA) to escape to the U.S. where they would remain in exile for over 5 years as they waited for the threat to subside.

Circumstances became increasingly grave. Mauricio Ávilez, one of the young lawyers and a member of the Church who worked to document specific people's stories of displacement, helping to determine their rights to redress, was put in prison after arrest on "trumped-up" charges. His cell-mate, Alfredo Correa de Andreis (another humanrights worker) was released and soon found shot to death, with the assassination largely believed to have been ordered by either the Colombian authorities or by the paramilitaries 
who had taken control of the area. It was at this moment that Huigita began most urgently advocating for accompaniment. At IPC request, a delegation from the PC(USA) came quickly to offer any assistance. The group went to the prison where Mauricio was being held and prayed outside of his prison cell until he was released by the authorities.

One of the members of the delegation was the moderator of the PC(USA) at the time, Rick Ufford-Chase, who had been a former Director of the Presbyterian Peace Fellowship (PPF). PPF has been the activist arm of the PC(USA), having been created during World War II to provide support to conscientious objectors, and it is a group avowedly committed to nonviolent engagement. Ufford-Chase responded to Huigita's request by getting in contact with the PPF community, and communicating the desperation of the situation to them. The PPF agreed to facilitate an initial round of accompaniment, to call for and send volunteers immediately, while in the meantime the IPC, PC(USA) and PPF worked to design an infrastructure which would sustain a protective accompaniment program. The PC(USA) decided to commit to an accompaniment program for an initial 5-year period, sending one pair of long-term accompaniers who would stay there through the duration, while they also facilitated the coming and going of short-term pairs who would stay for 30 days before returning to the States, being replaced by the next pair. In 2009 the IPC and PC(USA) conducted its 5 year review of the program and decided to continue with it. To date the accompaniment program has trained over 100 volunteers, 70 of which have served as accompaniers in Colombia. 


\section{IPC ACCOMPANIMENT: THE ETHIC OF PARTNERSHIP}

Two are better than one, because they have a good reward for their toil. For if they fall, one will lift up the other; but woe to one who is alone and falls and does not have another to help. Ecclesiastes 4:9-10

It can be difficult to assess the success of TPNI initiatives. Other similar programs have noted, "Although it would be ideal, we really do not have a quantifiable way to analyze success. ... it is extremely difficult to measure a negative - how do you measure whether you prevented something from happening? For instance, there is really no way to know if the accompaniment we provided in a specific situation prevented a violent and dire situation from occurring" (Duncan, Zissaman, and Savaiano 2009, p. 97).

Nevertheless, testimonies offered by those interviewed imply a few conclusions about the efficacy of the IPC accompaniment program in particular and the nature of this transnational alliance in general. The consensus they suggest is that the theological commitments and institutional infrastructures distinctly advantage the advocacy work of the religious community in numerous practical and material ways based on both partnership ethics theologically elaborated and religious infrastructure which connects communities at the grassroots level. Moreover, an awareness of the historical context of inequality and colonial dynamics has resulted in a robust commitment to mutuality. The backdrop of a complex and often inequitable history between the IPC and PC(USA) serves as a rich, affective resource for appreciating the dynamics of respect and mutuality so vital to a worthwhile transnational alliance.

During interviews conducted with Zarate, the Secretary for the Office of Diaconia of the IPC, which administers the accompaniment program, he explained that the object of the program is both to "ver y dejarse ver," to see and to be seen. Accompaniers are not 
there simply as unarmed bodyguards. Long term accompanier Richard Williams explained that, although other groups emphasize the bodyguard model, for them, the “really good accompaniment happens when things are boring and you're just going along people's regular life, rather than at times when there is a police raid or somebody is locked up; that's not the kind of goal we want out of accompaniment." Rather their model is "much more oriented towards an idea of accompaniment, of solidarity, of learning about the life and struggles of this Church here, rather than the idea that 'if the gringos are here, they won't shoot us."' Protective accompaniers in 2006, Britt Johnston and Danna Larsen described their experience: "The objective is to 'be present,' living in solidarity with our Colombian sisters and brothers... As North American witnesses, we have a special capacity to embarrass violators of human rights."

Time and time again, those involved with the program talked about it, not only as an intervention for nonviolence focused on results, but also as an ecclesiastic model and a spiritual commitment focused on solidarity. This was often described in terms of "walking alongside," used interchangeably with accompaniment and "pastoreando," pastor-ing. Because the Colombian conflict is so longstanding, with many people referring to the "NGOization" of advocacy, what Williams termed the "Colombian advocacy complex," it has become easier to compare the methods of particular groups operating within the region. Speaking specifically about other NGO organizations which advocate around the Colombian conflict, Williams indicated, "The focus on how to be partners... is all too rare." His partner and fellow accompanier, the reverend Mamie Broadhurst, confirmed that the IPC program is unique in its reciprocal commitment to "obeying the partnership ethic of listening to their partner and responding." 
For the IPC, the emphasis on the universal Church and its mandate for solidarity and mutuality create results that go beyond what would normally be seen in the works of NGOs, accompaniers confirmed. Zarate locates the accompaniment program firmly within the context of the centrality of the gospel, the Good News: "The role of the Church is not to judge but to redeem, to offer the Good News, and this is the job that the office of Diaconia has given itself. What is the role of the Church today? The Good News. What is the center of the Good News? The Good News. It is very important to construct processes of life improvement, to show that Christ really has changed one's life. Now, does one forget about the justice? No, because the justice of Christ brings the peace."

While the presence of accompaniers (dejarse ver) has indeed decreased the threats of violence against the community, the stronger impact of the program may be the other aspect of the mission (ver). Accompaniers go back to the United States and often times become heavily involved in lobbying the U.S. government to pursue policies that encourage justice and peace in the region, something contrary to the historical role that the U.S. has played there. For example, Williams told of one particular story in which a group of accompaniers from the Winnebago presbytery in Wisconsin visited the Urabá presbytery, which has suffered the most violence of any of the IPC communities. While travelling on a bus from Urabá to Medellín and talking with some of the local pastors, it emerged that U.S. congressional money had been allocated to improve the particular road that they were travelling, although it had apparently been misappropriated and the road continued to be in a deplorable condition. When the accompaniers returned, they did their research and took it to their congressional leaders, pressuring them to investigate the 
misappropriation. To Williams, this is a prime example of the kind of grassroots linking which is advantaged by these religious networks. He mused,

I'm sure in Congress they are saying, 'How does he know what the status of the road between podunk and Medellín is?' But they said this is being misappropriated, they spoke with the State department and someone said, 'I'm impressed you know so much about this.' But no one's been to Colombia [in Congress] and no one's been to Urabá. So no one has seen this part of Colombia. But there is a group of Wisconsonians that are advocating for Urabá.

This is precisely the type of alliances that have begun to form since the beginning of the accompaniment program, which are indeed coalescing into transnational civil societies, that model of globalization from below, and geopolitics from below, creating spaces for alter-geopolitics, for sharing securities.

Broadhurst and Williams described the advocacy work of the accompaniment as fundamentally different from what is conducted via secular routes. While professional NGOs are masters of navigating the complexities of Capitol Hill, they often do so to the exclusion of understanding the needs of the actual people in Colombia. Because of the accompaniment program, however, a ceaseless cycle of accompaniers are returning to the U.S. every month having spent time listening to the members of the IPC communities.

Williams insisted that while

every organization here struggles to be heard with the professionals in Washington, sometimes they get on to something that makes a lot of sense in the U.S. congressional context, but it's not the focus here. And so our point is, how about Colombians prioritize what they should be doing on advocacy... and the U.S. people make it happen. And that's where the power differential here with the NGOs is huge... Sometimes the professionals in the U.S. have way better statistics or reports, 'Here's stuff we want to work on.' And it's easy for folks to say, 'Okay, whatever you think.' But we feel like there is a genuine need to let Colombians determine their own way. 
After a history of paternalism and colonial relations between members of the PC(USA) and those of the IPC, what became clear is that attention focuses expressly on partnership. Eventually the Winnebago presbytery signed a partnership with the presbytery in Urabá, agreeing to accompany one another for 4 years. A testimony to the historical imbalance of power and the sincerity of the new moment, the two communities agreed that during this first 4 years they would not talk about any money or projects. They recognized, Williams said, that "that usually kills things, when we start talking about how much money you are going to give us, slash, 'How we're going to help the poor people."' Recently, the first agreement expired and they've signed another one. This time around they have begun "very carefully" to see how they can work on projects, "but they're very clear and very conscious about having those conversations be with dignity and respect, and not in a subservient position, but [rather] having two partners talk about, 'How are we going to do this together?"' Broadhurst emphasized that the difference is that they are doing it now from a genuine place of relationship. There is obviously a very real resource gap between the communities, and so the goal is not to ignore this reality. "Questions about assistance are fair and warranted, but there is difference between [collaborating with] someone you know and writing a check for something you see on the television."

Williams affirmed that while there are areas that NGOs are stronger than the grassroots efforts that have stemmed out of the accompaniment program and the transnational networks they have led to, (because the NGOs have the resources and clout to function professionally in Washington) he suggested that the lack of a commitment to listening and mutuality ultimately undermines those advantages: 
the human rights organizations try to do some of the same stuff, but I think the Church actually might be better, a better model, from what I've seen... a better model of having the people in the U.S. respond to the direction of Colombians for advocacy, as opposed to NGOs. Our advocacy is much less people in Washington and more people who have been here, organizing grassroots efforts to contact Congress, write letters to the editors, things like that, versus very centralized U.S. lobbying efforts that the NGOs have, which is more centralized, and more professionalized.

Broadhurst continued to express that there is a difference in effectiveness, that the NGOs may be more effective sometimes, but that it's about the model: "it's also a model of how you hear, you come down and hear people's experience and you go back and you say what it is people are saying." She concluded that while many of the people involved in accompaniment may never be plugged into these larger lobbying organizations and not so plugged into Washington,

the voices they are hearing from consistently and always are from the Church in Colombia that's saying, 'This is a concern that we have, this is what we'd like you to do,' and so they may not then, effectiveness-wise, hit the Congress at the particular time when an issue is coming up [that Congress will respond to], but they are obeying the partnership ethic of listening to their partner and responding.

While analyses of transnationalism and alliance are on the rise, insufficient attention is being paid to the potential for religious networks to link and advocate across conventional boundaries. An initial study of the IPC shows that this particular religious network has been uniquely enabled to respond to conditions of violence and impunity. Despite a history of colonial relations and discrimination with counterpart communities in the U.S., the IPC has forged a strategy of transnational alliance, driven by a program of accompaniment that was articulated in response to a specific threat, and is engendering new types of relations across space. While these strategies have not been without their complexities or problems, they have allowed bodies to connect with one 
another in a way that, while still paying attention to a history of domination and marginalization, challenges the global order as they create space for peace and articulate alternative configurations of solidarity.

In addition to the accompaniment program, which has been the focus of this particular study, the number and impact of the other transnational alliances in which the IPC has engaged is substantial and merits attention. There are informal agreements signed between particular churches now, such as the one described above between the Winnebago Presbytery in Wisconsin and the Urabá Presbytery. Often referred to as "hermandades" or "hermanamientos," IPC communities in all three of the Colombia synods have entered into similar relationships with the Miami Valley Presbytery of Ohio, the Tres Rios Presbytery of Texas, the Chicago Presbytery of Illinois, and the San Fernando Presbytery of California. These communities send delegations to visit one another, to share special services over Skype, and to commit to labor together in the struggle for justice and peace. These communities organized with other groups to have several days of action during the lead up to the U.S.-Colombia Free Trade Agreement (CFTA), which was signed into law by President Obama on October $21^{\text {st }}, 2011$. There was a week-long hunger fast coordinated between IPC and PC(USA) community members, which coincided with days of action and education to protest the CFTA. To think about the reconceptualization of societies proposed by emergent theories of transnationalism, along with the potential for critical-geopolitical responses to the dominant socio-economic system, while further adding the element of a network of transnationally coordinated spiritual practices, such as the hunger fast, to protest and 
promote awareness of a piece of top-down capitalist, globalization policy may begin to allow for a textured appreciation of the kind of work that this network engages.

In addition to affiliating with a range of ecumenical councils and movements, such as the World Council of Churches and the Consejo Latinoamericano de Iglesias (CLAI), the IPC has deepened its commitments to educational initiatives. Through informal arrangements established through various Church leaders and connections, the IPC has established exchange initiatives with McCormick Seminary in Chicago, Lakeland College in Wisconsin, and Lee University in Cleveland, TN. Students and Staff from the IPC's Universidad Reformada and Colegio Americano have been able to spend time at these schools while the U.S. institutions have sent both delegations and staff to attend or lead seminars in Colombia, and teach at the schools. I actually had a role in developing the newly formed informal affiliation with Lee University. My undergraduate Spanish teacher discussed in the introduction had long hoped to begin a program that would further the advocacy and educational initiatives of the IPC. After having seen the activities the IPC was engaged in during my first visit in 2010, I decided to move to Barranquilla and teach at the Reformada and Colegio after completing my undergraduate degree in January of 2011. Although I taught a range of classes from $4^{\text {th }}$ grade to the University level, on topics such as social studies, religion and international language test preparation, my main assignment as a teacher was to help further develop English curriculum.

I was the first, and experimental, 'exchange' experience from Lee University, but since leaving in August of 2011 to begin a Master's program at Florida International, one to two Lee graduates have volunteered to teach and work with the IPC every semester, 
with the most recent volunteer, Renee Whyte, extending her stay to a two-year commitment. These exchanges have allowed the IPC institutions to vastly expand upon their English language pedagogy from $1^{\text {st }}$ grade through to the graduate level and prepare students for the challenges of a the volatile labor market; in addition to the language skills, those students are able to share in and reap from the spiritual and ethical commitments that have guided the IPC community for so long. That such rich and impactful exchanges and alliances have formed out of and in response to such a long, complex history of paternalism, colonial dynamics, and the religious manipulations related to capital expansion surely merits a more sustained reflection, not only on account of what it may mean for how we prioritize what's needed in transnational alliances, but also in order to reconsider how religious networks and religious values altogether may relate to broader discussions of solidarity and social transformation.

\section{CONCLUSIONS}

The history of the IPC community is one microcosm of larger changes that have taken place globally in the way that people think about social transformation. Stemming from colonial models, and times when the colonial model of social relations was more unapologetic than it is now, white, educated, wealthy North Americans travelled to Colombia to spread the perceived goods of their religious expression. Although many Colombians have seen this work as having shared some important resources with the country, principally immaterial ones, larger ideological concepts such as progress, modernity and manifest destiny inevitably framed the relationship. This case is important because, as it was foregrounded by reflections about the ambivalent ways that Christian 
movements may relate to the oppressive system of modern capitalism, the IPC finds its beginnings as, in part, the first pawn in a geopolitical struggle between the Liberals and Conservatives of Colombia. The Presbyterians were invited and often used in order to facilitate policies of capital expansion and foreign intervention within the nation.

Nevertheless, as time went on and the IPC struggled to establish itself despite the brutal national conflict, winds shifted and people within the IPC, the region, and, indeed, the world began to rethink what social progress might look like in a pluriform world. As Colombians sought to gain autonomy within the IPC from the PC(USA), they were often hamstrung by the material limitations of financial resources and discourses that elevated the missionary/foreigner as most capable of impacting Colombian society. The events and impact of the Medellín Episcopal Conference reflected other seismic shifts taking place in the world, and helped to generate a further momentum as people insisted upon systems - be they theological, economic, or social — that reflect local contexts, concerns and priorities. The rise of more radical theologies and the participation of rare missionaries such as Richard Shaull helped to create the space necessary for a generation of leadership committed to autonomy, justice and solidarity to form. Leaders like Fals Borda emerged, developing creative programs that took advantage of the modern sciences in order to show people that their knowledge counted and that if they worked together they could gather their resources and capacities to transform their communities.

Within the IPC, as the emergence of a national leadership replaced the missionary model, they went through ups and downs as they sought to develop a relevant Christian response to the political and economic conflicts which have plagued the country. After increasingly realizing that the only way to transform their communities - and their 
relationship with the U.S. Presbyterians - was through the education meant to generate new leaders, they began a Seminary program, which has since become an accredited university. The IPC has become self-sustaining, and after a respite of relations with the PC(USA), they reached out again to ask in what ways might their common history and commitment together, problematic as it has been, enable them to, rather than growing weary in commitments to social transformation, press further in what they see as a spiritual imperative. What has resulted has been a productive, and, moreover, carefully executed strategy of transnational alliance, coalescing with what some scholars have termed globalization from below or the global justice movement.

Through the IPC Accompaniment Program, U.S. citizens travel to Colombia, this time not as missionaries, that is, they're not there to impart something, but rather to share in solidarity, to encourage people and let them know that there are communities outside of the country invested in their struggle, lobbying governments, writing letters, committed to soulful prayer and fasting in a spirit of accompaniment. What the IPC case shows about the potential for religious networks to uniquely enable strategies of solidarity and alliance is the rich and durable testimony of old, weathered, worn-out (-in) relationships. What is fundamentally at stake in transnational alliance is power disparity. Strategies of transnational alliance function precisely because one group is distinctly better-positioned vis-á-vis centers of power than the other group. What the history of the IPC shows, along with the interviews presented in the final section, is not that members of the IPC or PC(USA) have transcended the power disparity, but rather that they have lived it and committed to a deep remembering of this intermingled history, with faces still turning red when recalling some of the activities of recent missionaries. The suggestion 
about this case is that, to employ a strategy that utilizes fundamental power disparity, there is an advantage in having an established, even humiliated, but communicative, and on-going relationship — something that, perhaps, only a long-standing and intimate relationship such as those established through transnational religious networks can employ.

William Faulkner wrote, "The past is not dead. It's not even past." While NGOs and civil society groups may have a strong commitment to and, as is often the case, far better financial resources for engaging in transnational activism, a cursory review of the IPC history reminds us that the most important resource that foreign entities interested in participating in the social transformation of vulnerable communities can offer is their ability to listen. These stories of the IPC relationships transitioning from paternalism and inequality to mutuality and solidarity continue to complicate those narratives that simply suggest that Christianity is the official religion of the capitalist system. Similar to Bartolomé de las Casas, privileged U.S. citizens travel to Colombia through the PC(USA) delegations or the protective accompaniment program, and as German Zarate explained above, the goal for these U.S. citizens is not only to be seen, but also to see. The story about the group from the Winnebago Presbytery who went to congress to interrogate the case of misappropriated funds for the rode to Urabá shows that this isn't some simple story of one group of privileged people helping some others in need, but rather it is a true story of social transformation. North Americans return to the United States with a genuine passion to see justice fulfilled, and they engage in and advocate for U.S. policy that makes a material difference and challenges the status quo of top-down political and economic systems. 
In addition to this, members of these disparate communities have a life-orienting commitment to a shared faith-tradition that causes members of both sides to stretch themselves far beyond the ordinary limits of comfort and compunction as they struggle, first, for one another, and second, towards something common. This isn't to discredit or argue against the merits of conventional methods of transnational alliance as practiced by NGOs and like-minded political groups. Rather, within the context of a world that was supposed to have dissolved the value of religion by now (according to theories of modernity) and that often still considers religion to be either a clingy obstacle or negligible trifle to larger discussions of social transformation, it is perhaps worth noticing that, right now, groups with long, problematic, colonial histories of discrimination are trudging through the work of forgiveness and reconciliation, Christianity's supposed fundamentals, in order to engage strategies of resistance that prefigure our notions of a transformed society. Such cases, and there are surely others, and their lessons, may prove vital to discussions of alliance, solidarity and social transformation. 


\section{BIBLIOGRAPHY}

Aquero, Miguel Angel Mansilla. "Pluralismo, subjetivización y mundanización. El impacto de la secularización en el neopentecostalismo chileno.” Polis19. (2008): p. 1-13.

Aquino, Marí Pilar, and Nuñez María José. Feminist Intercultural Theology: Latin Explorations for a Just World. Maryknoll, NY: Orbis, 2007.

Aristizábal, García José. Metamorfosis: Guerra, Estado Y Globalización En Colombia. Bogotá: Ediciones desde abajo, 2007.

Althaus-Reid, Marcella. Indecent Theology. New York, NY: Routledge, 2000.

Alves, Rubem. "As idéias Teológicas e os seus Caminhos pelos Sulcos Institucionais do Protestantismo Brasileiro.” In Históia da Teologia na América Latina. São Paulo: Ediçōes Paulinas, 1981.

Avilés, William. Global Capitalism, Democracy, and Civil-military Relations in Colombia. Albany: State University of New York, 2006.

Bandy, Joe, and Jackie Smith. Coalition Across Borders: Transnational protests and the Neoliberal Order. Lanham, Maryland: Rowman \& Littlefield Publishers, 2005.

Barker, Isabelle. "Charismatic Economies: Pentecostalism, Economic Restructuring, and Social Reproduction." New Political Science. Vol. 29, No. 4 (2007): p. 407-27.

Bidegain, Ana Maria. "Christianity in Latin America, 1910-2010” Atlas of Global Christianity, eds. Todd Johnson \& Kenneth Ross. Edinburgh: University of Edinburgh Press, 2010.

Bidegain, Ana Maria. "Rethinking the Social and Ethical Functions of a History of World Christianity." Journal of World Christianity. Vol. 1, No. 1 (2008): p. 54-87.

Bonino, José Miguez. Protestantismo y Liberalismo en América Latina. San José: DEI, 1985.

Brackenridge, Rafael, and Francisco Ordoñez. Iglesia Presbiteriana: A history of Presbyterians and Mexican Americans in the Southwest. San Antonio: Trinity University Press, 1974.

Brecher, Jeremy, Tim Costello, and Brendan Smith. Globalization from Below: The Power of Solidarity. Cambridge, Mass.: South End Press, 2000.

Brodzinsky, Sibylla. “Trade Deals: US-Colombia FTA Ratified, but Will It Help 
Colombian Workers?" The Christian Science Monitor - CSMonitor.com. Retrieved from < http://www.csmonitor.com/World/Americas/2011/1013/Tradedeals-US-Colombia-FTA-ratified-but-will-it-help-Colombian-workers>.

Brouwer, Steve, Paul Gifford, and Susan Rose. Exporting the American Gospel: Global Chrstian Fundamentalism. New York, NY: Routledge, 1996.

Brusco, Elizabeth. The Reformatin of Machismo: Evangelical Conversion and Gender in Colombia. Austin: University of Texas Press, 1995.

Castillo Cárdenas, Gonzalo. "Los Cristianos y la Lucha por un Nuevo Orden Social en América Latina." In Cristianismo y Sociedad. Mondevideo: ISAL, 1966.

Castillo Cárdenas, Gonzalo. "Violencia contra Sacerdotes en Colombia." Cristianismo y Sociedad. Montevideo: ISAL, 1969.

Clark, Howard. People Power: Unarmed Resistance on Global Solidarity. London: Pluto, 2009.

Chomsky, Aviva. Linked Labor Histories: New England, Colombia, and the Making of a Global Working Class. Durham N.C.: Duke UP, 2008.

Cogua, Jasney E. Colombia's Rural Communities: Displacement, Plan Colombia and Alternative Models. Ohama, NE: University of Nebraska at Ohama, 2003.

Colby, Gerard, and Charlotte Dennett. Thy Will Be Done: The Conquest of the Amazon: Nelson Rockefeller and Evangelism in the Age of Oil. New York, NY: HarperCollins, 1995.

Collier, Peter, and David Horowitz. The Rockefellers: An American Dynasty. New York, NY: Hold, 1976.

Colmenares, G. Partidos politicos y clases sociales. Bogota: Universidad de los Andes, 1968. P. 176-177.

Cross, Terry. Answering the call in the Spirit: Pentecostal reflections on a theology of vocation, work and life. Cleveland, TN: Lee University Press, 2007.

d'Escoto, Miguel. Antiimperialismo Y Noviolencia. Mexico: Ocean Sur, 2009.

Daly, Herman. Ecological Economics and Sustainable Development. Northampton, Massachusetts: Edward Elgar Publishing, 2007.

Destler, I.M.; Priscilla Clapp, Hideo Sato, and Haruhiro Fukui. Managing an Alliance: The Politics of U.S.-Japan Relations. Washington, D.C.: The Brookings 
Institution, 1976.

Dittmer, Jason. "Intervention: religious geopolitics." Political Geography. Vol. 26, No. 7 (2007): p. 737-739.

Dowler, Lorraine, and Joanne Sharp. “A feminist geopolitics?” Space \& Polity. Vol. 5, No. 3 (2001): p.165-176.

Duncan, Mel, Mark Zissaman, and Patrick Savaiano. "Nonviolent Peaceforce: A realistic choice for the Future." The New Humanitarians: Inspirations, Innovations, and Blueprints for Visionaries. Ed. Stout, Christ E. Westport, CT. Praeger Publishers, 2009.

Eastwood, Linda. "Ethical Issues in International Human Rights Accompaniment: The Case of the Colombian and U.S. Presbyterian Churches." UNPUBLISHED, 2009.

Elden, Stuart. Terror and Territory: The Spatial Extent of Sovereignty. Minneapolis: University of Minnesota, 2009.

Escobar, Arturo. Encountering Development: the Making and Unmaking of the Third World. Princeton, NJ: Princeton UP, 1995.

Escobar, Arturo. Territories of Difference: Place, Movements, Life, Redes. Durham: Duke UP, 2008.

Eugene, Luis Enrique, and Liam Mahoney. Unarmed Bodyguars: International Accompaniment for the Protection of Human Rights. Sterling, Virginia: Kumarian Press, 1997.

Fals Borda, Orlando. Conocimiento y Poder Popular. Bogotá: Siglo Veintiuno, 1986.

Fals Borda, Orlando. "El Desafío de la Civilización Moderna." Protestantismo e Imperialismo na América Latina. Ed. Cesar Waldo et al. Petropolis: Voces, 1968.

Fals Borda, Orlando. "Peoples' SpaceTimes in Global Processes: The Response of the Local." Journal of World-Systems Research. Vol. 1, No. 3 (2000): p. 624-634.

Fals Borda, Orlando. "Subversión y Desarollo: el caso de América." Cristianismo y Sociedad, 1971.

Fals Borda, Orlando. Subversion and Social Change in Colombia. New York: Columbia University Press, 1969. 
Fanta, Andrea. "Imágenes del tiempo en El ovlido que seremos de Héctor Abad Faciolince." Letral. No. 3 (2009): p. 28-40.

Ferguson, James. The Anti-politics Machine: "development," Depoliticization, and Bureaucratic Power in Lesotho. Minneapolis: University of Minnesota, 1994.

Fukuyama, Francis. The End of History and The Last Man. New York, NY: Avon Books, Inc., 1992.

Galeano, Eduardo. Open Veins of Latin America: Five Centuries of the Pillage of a Continent. New York: Monthly Review, 1997.

Gibson-Graham, J. K. The End of Capitalism (as We Knew It): a Feminist Critique of Political Economy. Cambridge, MA: Blackwell, 1997.

Gish, Steven. Desmond Tutu: A Biography. Westport, CT: Greenwood Press, 2004.

Gomez, Mauricio Avella. “Antecedentes Históricos de la Deuda Externa Colombiano. La Paz Británica." REI. Vol 9 (2003): p. 90-127.

Gonzáles, Fernán. "La Iglesia católica y el Estado colombiano (1886-1930).” Nueva Historia de Colombia. Bogotá: Planeta, 1989.

Grandin, Greg. Empire's Workshop: Latin America, The United States, and the Rise of the New Imperialism. New York: Owl Books, 2006.

Gregory, Derek. The Colonial Present: Afghanistan, Palestine, and Iraq. Malden, MA: Blackwell Pub., 2004.

Guidry, John, Michael Kennedy, and Mayer Zald. Globalizations and Social Movements: Culture, Power, and the Transnational Public Sphere. The University of Michigan Press, 2000.

Harvey, David. The New Imperialism. New York, NY. Oxford University Press, 2003.

Hasenclever, Andreas, and Volker Rittberger. "Does Religion Make a Difference? Theoretical Approaches to the Impact of Faith on Political Conflict." Millennium - Journal of International Studies. Vol. 29, No. 3 (2000): p. 641-675.

Healey, Declan. "The U.S. - Colombia free trade agreement - A historical placement of the FTA." Theses and Dissertations. Retrieved from $<$ http://via.library.depaul.edu/etd/10>, 2010.

Heschel, Abraham Joshua. God in Search of Man; a Philosophy of Judaism. New York: Farrar, Straus \& Cudahy, 1955. 
Hofstadter, Richard. "The Paranoid Style in American Politics.” Harper's Magazine. Fall (1964): p. 77-86.

Hosseini, S. A. Hamed. "Global Complexities and the Rise of Global Justice Movement: A New Notion of Justice". The Global Studies Journal Vol 2, No. 3 (2009): 1536.

Holland, Dorothy, and Jean Lave. History in Person: Enduring Struggles, Contentious Practice, Intimate identities. Santa Fe: School of America Research, 2001.

Hylton, Forrest. Evil Hour in Colombia. London: Verso, 2006.

Hyndman, Jennifer. "Beyond either/or: a feminist analysis of September 11th." $A C M E$. Vol. 2, No. 1 (2003): p.1-13.

Ianni, Octavio. Imperialismo y Cultura de la Violencia en America Latina. Mexico: Siglo XXI Editores, 1971.

Juergensmeyer, Mark. The New Cold War. Berkeley: University of California Press, 1993.

Juergensmeyer, Mark. Terror in the Mind of God. Berkeley: University of California Press, 2000.

Kline, Harvey. Historical Dictionary of Colombia. Lanham, MD: 2012.

Koopman, Sara. "Alter-geopolitics: Other securities are happening." Geoforum. Vol. 42 (2011): p. 274-284.

Langan, Thomas. The Catholic Tradition. Columbia, MO: University of Missouri Press, 1998.

Levitt, Peggy and Nina Glick Shiller. "Conceptualizing Simultaneity: A Transnational Social Field Perspective on Society." International Migration Review. Vol. 38, No. 3 (2004): p. 1002-1039.

Livingstone, Grace. Inside Colombia: Drugs, Democracy and War. New Brunswick, NJ: Rutgers University Press, 2004.

Loveman, Brian. Addicted to Failure: U.S. Security Policy in Latin America and the Andean Region. Lanham, MD: Rowman \& Littlefield, 2006.

Lopes, Javier Ocampo. "El Maestro Orlando Fals Borda Sus Ideas Educativas y Sociales para el Cambio en la Sociedad Colombiana.” Rhela. Vol. 12 (2009): p. 13-41. 
Mackay, Juan. El Otro Cristo Español. España: Casa Unida de Publicaciones, 1952.

Maduro, Otto. “'Religion' under Imperial Duress: Postcolonial Reflections and Proposals." Review of Religious Research. Vol. 45, No. 3 (2004): p. 1-25.

Mansilla, Miguel Angel. “El neopentecostalismo chileno.” El Cotidiano. Vol. 22, No. 143 (2007): p. 106-114.

Martin, Bernice. "New Mutations of the Protestant Ethic among Latin American Pentecostals." Religion. Vol. 25, No. 2 (1995): 106-114.

Massey, D. For Space. London: SAGE, 2005.

Mbembé, Achille. On the Postcolony. Berkeley: University of California, 2001.

Mignolo, Walter, and Arturo Escobar. Globalization and the Decolonial Option. London: Routledge, 2010.

Mignolo, Walter. The Idea of Latin America. Malden, MA: Blackwell Pub., 2005.

Miller, Francesca. Latin American Women and the Search for Social Justice. Hanover, NH: University Press of New England, 1991.

Moreton, Bethay. "The Soul of Neoliberalism." Social Text. Vol. 25, No. 3 (2007): p. 102-143.

Müller, Andreas, Arno Tausch, Paul Michael Zulehner, and Henry Wickens. Global Capitalism, Liberation Theology, and the Social Sciences: An Analysis of the Contradictions of Modernity at the Turn of the Millennium. Huntington, NY: Nova Science, 2000.

Ocampo López, Javier. Las ideologías en la Historia Contemporánea de Colombia. Mexico: Universidad Nacional Autónoma de Mexico. Centro de Estudios Latinoamericanos (1972): p. 16-21.

O'Hanlon, M. and Wolfowitz, J. Using the Colombia Model in Afghanistan. Brookings Institute. 2011.

Ordóñez, Francisco. Historia del Cristianismo evangélico en Colombia. Alianza Cristiana y Misionera, 1956.

Oslender, Ulrich. "Another History of Violence: The Production of 'Geographies of Terror' in Colombia's Pacific Coast Region." Latin American Perspectives. Vol. 35, No. 5 (2008): p. 77-102. 
Oslender, Ulrich. Comunidades Negras y Espacio en el Pacifico Colombiano: Hacia un Giro Geográfico en el Estudio de los Movimientos Sociales. Bogotá: Instituto Colombiano de Antropología E Historia/Universidad Colegio Mayor de Cundinamarca, Universidad del Cauca, 2008.

Oslender, Ulrich. "Spaces of Terror and Fear on Colombia's Pacific Coast." Violent Geographies: Fear, Terror, and Political Violence. Ed. Gregory and Predd. New York, NY: Routledge, 2007.

Østergaard-Nielsen, Eva. "The Politics of Migrants' Transnational Political Practices." International Migration Review. Vol. 37 No. 3 (2003): p. 760-786.

Perez Benavides, Isay, and Gonzalo Castillo Cárdenas. La Influencia Religiosa en la Conciensia Social de Orlando Fals Borda. Barranquilla; CUR, 2010.

Perkins, John. Confessions of an Economic Hitman. San Francisco, CA: Berett-Koehler Pub., 2004.

Prada, Diego Otero. El Papel De Estados Unidos En el Conflicto Armado Colombiano. De la Doctrina Monroe a La Cesión de Siete Bases Militare. Bogotá: Ediciones Aurora, 2010.

Rodríguez, Javier. “Antecedentes y Transfondo historico de la Iglesia Presbiteriana de Colombia.” UNPUBLISHED, 1992.

Rodríguez, Javier. "Primeros intentos de establecimiento del protestantismo en Colombia." In Historia del Cristianismo en Colombia: Corrientes y Diversidad. Dir. Ana Maria Bidegain. Bogotá: Taurus, 2004.

Roldán, Alberto. "La teología contextual de Richard Shall: del paradigm de la revolución al paradigm de la liberación.” Teología y cultura. Vol. 13 (2011): p. 27-47.

Salamanca, Helwar Hernando Figuero. "Historiografía sobre el protestantismo en Colombia. Un estado del arte, 1940-2009." Anuario Colombiano de Historia Social y de la Cultura. Vol. 37 No. 1 (2010): 191-225.

Santiago-Vendrell, Angel. Contextual Theology and Revolutionary Transformation in Latin America: The Missiology of M. Richard Shaull. Eugene, OR: Pickwick Publications, 2010.

Shaull, Richard. "Entre Jesus e Marx: Reflexões sobre os anos que passei no Brasil." De Dentro do Furacâo: Richard Shaull e os Primórdios da Teologia de Liberataçâo. Sao Paulo: CEDI-CLAI, 1985. 
Simons, Geoff. Colombia: A Brutal History. London: Saqi, 2004.

Sinclair, John. "Hacia un protestantismo colombiano y venezolano." Historia General de la Iglesia en América Latina, Tomo VII, Colombia y Venezuela. Ed. Rdolfo Ramón de Roux. Salamanca: CEHILA-Ediciones Sígueme, 1981.

Slater, David. Geopolitics and the Post-colonial: rethinking North-South Relations. Oxford, UK: Blackwell Publishing, 2004.

Smith, Christian. Disruptive Religion: The force of faith in Social-Movement Activism. New York, NY: Routledge, 1996.

Smith, Christian. Resisting Reagan: The U.S. Central America Peace Movement. Chicago, IL: University of Chicago Press, 1996.

Smith, Jackie. Social Movements for Global Democracy. Baltimore, Maryland: John Hopkins University Press, 2008.

Stoll, David. Fishers of Men or Founders of Empire? The Wycliffe Bible Translators in Latin America. London: Zed Books, 1983.

Tate, Winifred. Counting the Dead: The Culture and Politics of Human Rights Activism in Colombia. Berkeley: University of California Press, 2007.

Toal, Gerard. Critical Geopolitics: The Politics of Writing Global Space. Minneapolis: University of Minnesota, 1996. Print.

Thomas, Scott. "Taking Religious and Cultural Pluralism Seriously: The Global Resurgence of Religion and the Transformation of International Society." Millinium - Journal of International Studies. Vol. 29, No. 3 (2000): p. 815-841.

Todorov, Tzvetan. The Conquest of America: The Question of the Other. New York: Harper \& Row, 1984.

Vasquez, Manuel. "Toward a new Agenda for the Study of Religion in the Americas." Journal of Interamerican Studies and World Affairs. Vol. 41, No. 4 (1999): p. 120.

Vertovec, Steven. "Conceiving and Researching Transnationalism." Ethnic and Racial Studies. Vol. 22, No. 2 (1999): p. 447-462.

Vickers, William. Review of Fishers of Men or Founders of Empire? The Wycliffe Bible Translators in Latin America, by David Stoll. American Ethnologist. Vol. 
11 (1984): p. 200-201.

Zinn, Howard. A People's History of the United States. New York: HarperCollins Publishers, 2003. 


\begin{tabular}{ll} 
& \multicolumn{1}{c}{ APPENDIX } \\
CCROF - & Concilio Colombiano de Obreros Fraternales \\
COEMAR - & Commission on Ecumenical Mission and Relations \\
JAARS - & Jungle Aviation and Radio Service \\
IPC - & Iglesia Presbiteriana de Colombia \\
SIL - & Summer Institute of Linguistics \\
TPNI - & Third Party Non-violent Intervention \\
WBT - & Wycliffe Bible Translators
\end{tabular}

